\title{
A probable case of heterochrony in the solutan Dendrocystites Barrande, 1887 (Echinodermata: Blastozoa) from the Upper Ordovician of the Prague Basin (Czech Republic) and a revision of the family Dendrocystitidae Bassler, 1938
}

\author{
FLEUR NOAILLES, BERTRAND LEFEBVRE \& LIBOR KAŠIČKA
}

\begin{abstract}
The morphology of the Late Ordovician solutan Dendrocystites is reevaluated based on more than 300 specimens from the Letná and Zahořany formations (Prague Basin, Czech Republic). This genus is reported for the first time from the Bohdalec Formation, and its presence is confirmed in the Vinice Formation. The morphology of all specimens of the stratigraphically older species D. barrandei (Sandbian) is identical to that of small to medium-size individuals of D. sedgwicki (Katian). Distinctive characters of D. sedgwicki occur only in the largest specimens, and are all size-related (more asymmetrical thecal outlines, stronger ornamentation, rosetting pattern of thecal plates, proliferation of platelets in the proxistele). Consequently, the transition from D. barrandei to D. sedgwicki is interpreted as the result of heterochronic processes, with the largest individuals of $D$. sedgwicki displaying hyperadult morphologies (hypermorphosis). Dendrocystites is locally abundant in both the Letná and Zahořany formations, but extremely rare in the deeper deposits of the Vinice and Bohdalec formations. This pattern coincides closely with first order fluctuations of the sea-level in the Prague Basin. The life orientation and implied feeding strategy of Dendrocystites and other solutans are both critically discussed. Several independent lines of evidence suggest that solutans were more likely detritus-feeders. Finally, it is proposed that two morphologically distinct patterns of dististele organization were elaborated independently from the polyplated, undifferentiated stalk-like appendage of Coleicarpus (plesiomorphic condition). Consequently, a major subdivision of the class Soluta into two main clades (Dendrocystitida ord. nov. and Syringocrinida ord. nov.) is proposed. The monophyly of each order is supported by apomorphies based primarily on the organization of the dististele and the morphology of the periproct. "Dendrocystites" rossicus is reinterpreted as belonging to an unknown genus of syringocrinids, whereas Heckericystis kuckersiana may represent a third species of Dendrocystites. - Key words: Blastozoa, Dendrocystites, Echinodermata, heterochrony, palaeoecology, Prague Basin, Soluta, Upper Ordovician.
\end{abstract}

NOAILleS, F., LeFEBVRE, B. \& KAŠIČKA, L. 2014. A probable case of heterochrony in the solutan Dendrocystites Barrande, 1887 (Echinodermata: Blastozoa) from the Upper Ordovician of the Prague Basin (Czech Republic) and a revision of the family Dendrocystitidae Bassler, 1938. Bulletin of Geosciences 89(3), 451-476 (10 figures). Czech Geological Survey, Prague. ISSN 1214-1119. Manuscript received August 5, 2013; accepted in revised form November 15, 2013; published online March 20, 2014; issued June 9, 2014.

Fleur Noailles (corresponding author), Department of Earth Sciences, University of Bristol, Wills Memorial building, Queen's road, Bristol BS8 1RJ, United Kingdom; fleur.noailles@bristol.ac.uk•Bertrand Lefebvre, UMR CNRS 5276 LGLTPE, bâtiment Géode, campus de la Doua, Université Lyon 1, 2 rue Raphaël Dubois, 69622 Villeurbanne cedex, France; bertrand.lefebvre@univ-lyon1.fr • Libor Kašička, Koněprusy 45, 26601 Beroun, Czech Republic; libor.kasicka@email.cz

Solutans are an extinct clade of non-radiate echinoderms, ranging from Cambrian Series 3 (Castericystis and Coleicarpus; Ubaghs \& Robison 1985, 1988; Daley 1995, 1996; Zamora et al. in press) to the Lower Devonian (Claritacarpus, Dehmicystis, and Rutroclypeus; Dehm 1934, Gill \& Caster 1960, Parsley \& Sumrall 2007, Rahman \& Lintz 2012). However, their taxonomic diversity and palaeobiogeographic distribution were both probably maximum in
Late Ordovician times (Caster 1967, Sprinkle \& Guensburg 2004, Lefebvre et al. in press). Abundant remains of Late Ordovician solutans were described from the periphery of most palaeocontinents, such as Avalonia (Wales; Daley 1992), Baltica (Estonia, Russia; Jaekel 1901, Rozhnov \& Jefferies 1996, Parsley et al. 2012), Gondwana and peri-Gondwanan areas (Bohemia, Morocco, Spain; Barrande 1887, Bather 1913, Gil Cid et al. 1996, Lefebvre 
et al. 2010), and Laurentia (Canada, NE United States, Scotland; Bather 1913, Parsley \& Caster 1965, Kolata 1973, Kolata et al. 1977, Jefferies 1990, Daley 1992).

Historically, the first solutan remains were described as Syringocrinus paradoxicus in the Upper Ordovician of Quebec by Billings (1859), who assigned them to the class Crinoidea. In 1867, solutan remains were briefly reported as Cystidea sedgwicki by Barrande in the Upper Ordovician of Bohemia (bande d4, Zahořany Formation). Barrande (1867, p. 179) was thus the first to suggest cystoid (i.e., blastozoan) affinities for solutans. Late Ordovician Czech solutans were formally described as Dendrocystites sedgwicki by Barrande (1887), based on abundant material collected mostly in the locality of Zahořany (bande $\mathrm{d} 4$, Zahořany Formation), as well as few specimens from Háj, Trubská (bande d2, Letná Formation), and Trubín (bande d3, Vinice Formation). The morphology and anatomy of Dendrocystites were both thoroughly reexamined by Bather (1913), who assigned all stratigraphically older specimens from the Letná Formation to a distinct species, $D$. barrandei. The distinction between the two species of Late Ordovician Czech solutans (D. barrandei and D. sedgwicki) was maintained by all subsequent authors (e.g., Regnéll 1945, Parsley \& Caster 1965, Caster 1967, Prokop \& Petr 1999). A third specific name, D. batheri (nomen nudum) was erroneously introduced by Havlíček \& Vaněk (1966, p. 57) in their faunal list of taxa occurring in the Zahořany Formation.

In the late 2000s, the discovery of abundant specimens of Dendrocystites sp. in the Upper Ordovician of the eastern Anti-Atlas (Lefebvre et al. 2007, 2010; Hunter et al. 2010) prompted their comparison with the two species of Dendrocystites described from coeval deposits in the Prague Basin. Reexamination of more than 300 specimens of Czech solutans deposited in both private and public collections in Berlin (Museum für Naturkunde), London (Natural History Museum), Prague (Czech Geological Survey, National Museum), Stockholm (Naturhistoriska riksmuseet), Vienna (Naturhistorisches Museum), and Villeurbanne (Université Lyon 1), confirmed the presence of two morphologically distinct solutans in the Upper Ordovician of the Prague Basin: D. barrandei-like specimens in the Letná Formation and D. sedgwicki-like in the Zahořany Formation (Bather 1913, Caster 1967). It also revealed the occurrence of Dendrocystites in the Vinice Formation (Barrande 1887, Bather 1913), and also in younger deposits of the Bohdalec Formation. However, the abundant material collected in the Zahořany Formation comprised not only $D$. sedgwicki-like solutans, but also $D$. barrandei-like ones and, more unexpectedly, specimens apparently intermediate in morphology between $D$. barrandei and D. sedgwicki. At a larger scale, the recent reports of a Dendrocystites-like solutan in the Early Devonian of Oklahoma (Parsley \& Sumrall 2007) and of solutans with relatively unusual morphologies in the Middle Ordovician of the Czech Republic (Prokop \& Petr 2003, Lefebvre et al. 2012) both question the validity and pertinence of the main systematic divisions generally identified within the class Soluta. Consequently, the aims of this paper are (1) to critically review the morphology and systematics of solutans, and in particular of the family Dendrocystitidae Bassler, 1938; (2) to discuss the morphological differences between D. barrandei and D. sedgwicki, so as to question the validity of their distinction as two separate taxa, and (3) to discuss the palaeoecology and mode of life of Dendrocystites.

\section{Solutan morphology and terminology}

Solutans are characterized by the possession of two articulated processes (Fig. 1): a short feeding appendage (brachiole) and a long stem-like structure (homoiostele; Lefebvre et al. 2012), generally inserted at opposite extremities of the body (theca).

\section{Theca and body openings}

In the oldest and most primitive forms (e.g., Castericystis, Coleicarpus, Minervaecystis, Plasiacystis), the theca is relatively inflated, ovoid, slightly longer than wide, and invariably made of a large number of unorganized, tesselated, polygonal, smooth skeletal elements (Thoral 1935; Caster 1967; Ubaghs 1970; Ubaghs \& Robison 1985, 1988; Daley 1995, 1996; Lefebvre et al. 2012). In contrast, in more derived solutans (e.g., Dendrocystites, Girvanicystis, Iowacystis, Scalenocystites), the theca is generally flattened and differentiated into two opposite surfaces with distinct morphologies: one side is convex, whereas the other one is usually more depressed and plano-concave (Bather 1913, Thomas \& Ladd 1926, Parsley \& Caster 1965, Caster 1967, Kolata et al. 1977, Daley 1992). Moreover, in derived solutans, the theca consists either in a high number of thin, tesselated platelets (e.g., Dendrocystites, Maennilia, Rutroclypeus; Bather 1913, Gill \& Caster 1960, Caster 1967, Rozhnov \& Jefferies 1996, Parsley et al. 2012), or a reduced number of thick and large skeletal elements (e.g., Belemnocystites, Iowacystis, Scalenocystites; Thomas \& Ladd 1926, Parsley \& Caster 1965, Parsley 1972, Kolata 1973, Kolata et al. 1977). In derived forms, thecal outlines can be either markedly asymmetrical and pear-shaped (e.g., Dendrocystoides, Girvanicystis, Maennilia, Scalenocystites; Bather 1913, Kolata 1973, Jefferies 1990, Daley 1992, Rozhnov \& Jefferies 1996, Parsley et al. 2012), or almost bilaterally symmetrical and sub-triangular (e.g., Iowacystis; Parsley \& Caster 1965, Kolata et al. 1977), rounded (e.g., Rutroclypeus; Gill \& Caster 1960), or subelliptical (e.g., Belemnocystites, Syringocrinus; Parsley \& 
Caster 1965, Parsley 1972). In some derived solutans (e.g., Belemnocystites, Girvanicystis, Iowacystis, Syringocrinus), thecal outlines are framed by enlarged, massive skeletal elements (or marginals), extending on both thecal sides (Parsley \& Caster 1965, Parsley 1972, Kolata 1973, Kolata et al. 1977, Daley 1992). In derived solutans, thecal plates can be either smooth (e.g., Dendrocystoides; Jefferies 1990), granular or pustulose (e.g., Belemnocystites, Iowacystis, Scalenocystites; Thomas \& Ladd 1926, Parsley \& Caster 1965, Caster 1967, Kolata et al. 1977), or ornamented either with radial ribs (e.g., Maennilia; Rozhnov \& Jefferies 1996, Parsley et al. 2012) or small spines (e.g., Heckericystis, Rutroclypeus; Hecker 1940, Gill \& Caster 1960). Strong ridges and protuberances are sometimes present on one (e.g., Girvanicystis; Caster 1967, Daley 1992) or both thecal surfaces (e.g., Dendrocystoides; Bather 1913, Jefferies 1990).

In many solutans, two small, distinct, slightly conical tubercles occur close to the insertion of the feeding appendage (e.g., Castericystis, Coleicarpus, Girvanicystis, Minervaecystis). Each of these two protuberances is perforated by a tiny orifice (Caster 1967; Ubaghs 1970; Ubaghs \& Robison 1985; Daley 1992, 1995, 1996). In Dendrocystoides, each of the two protuberances is pierced by several small orifices (Jefferies 1990). In some other solutans (e.g., Iowacystis, Scalenocystites), only one perforated tubercle is present, but it is then surrounded by several small pores (Parsley \& Caster 1965, Kolata et al. 1977). Finally, some other solutans (e.g., Maennilia) do not exhibit any perforated tubercle close to the insertion of the feeding appendage, but instead, numerous tiny orifices forming a sieve-like structure (Rozhnov \& Jefferies 1996, Rozhnov 2002, Parsley et al. 2012). Comparison with both modern and extinct echinoderms suggests that the two orifices located close to the insertion of the feeding appendage can be readily identified as the hydropore (single or multi-perforated, sieve-like opening) and the gonopore (single rounded hole; Thomas \& Ladd 1926, Bather 1928, Caster 1967, Ubaghs 1970, Kolata et al. 1977, Ubaghs \& Robison 1985, Jefferies 1990, Daley 1996, David et al. 2000, Smith 2005).

The theca of all solutans is pierced by a large orifice opening close to the insertion of the homoiostele. In the most primitive forms (e.g., Castericystis, Coleicarpus, Minervaecystis, Plasiacystis), this main thecal orifice is located at the summit of a large and high, cone-shaped, valvular pyramid, made of numerous, elongate, radial platelets (Ubaghs 1970; Ubaghs \& Robison 1985; Daley 1995, 1996; Lefebvre et al. 2012). In the solutan indet. from the Šarka Formation described by Lefebvre et al. (2012), this opening occurs as a tiny hole at the top of a low, almost flat, polyplated valvular structure, with circular outlines (see also Prokop \& Petr 2003). In Dehmicystis, Dendrocystoides, Girvanicystis, Maennilia and Rutroclypeus,

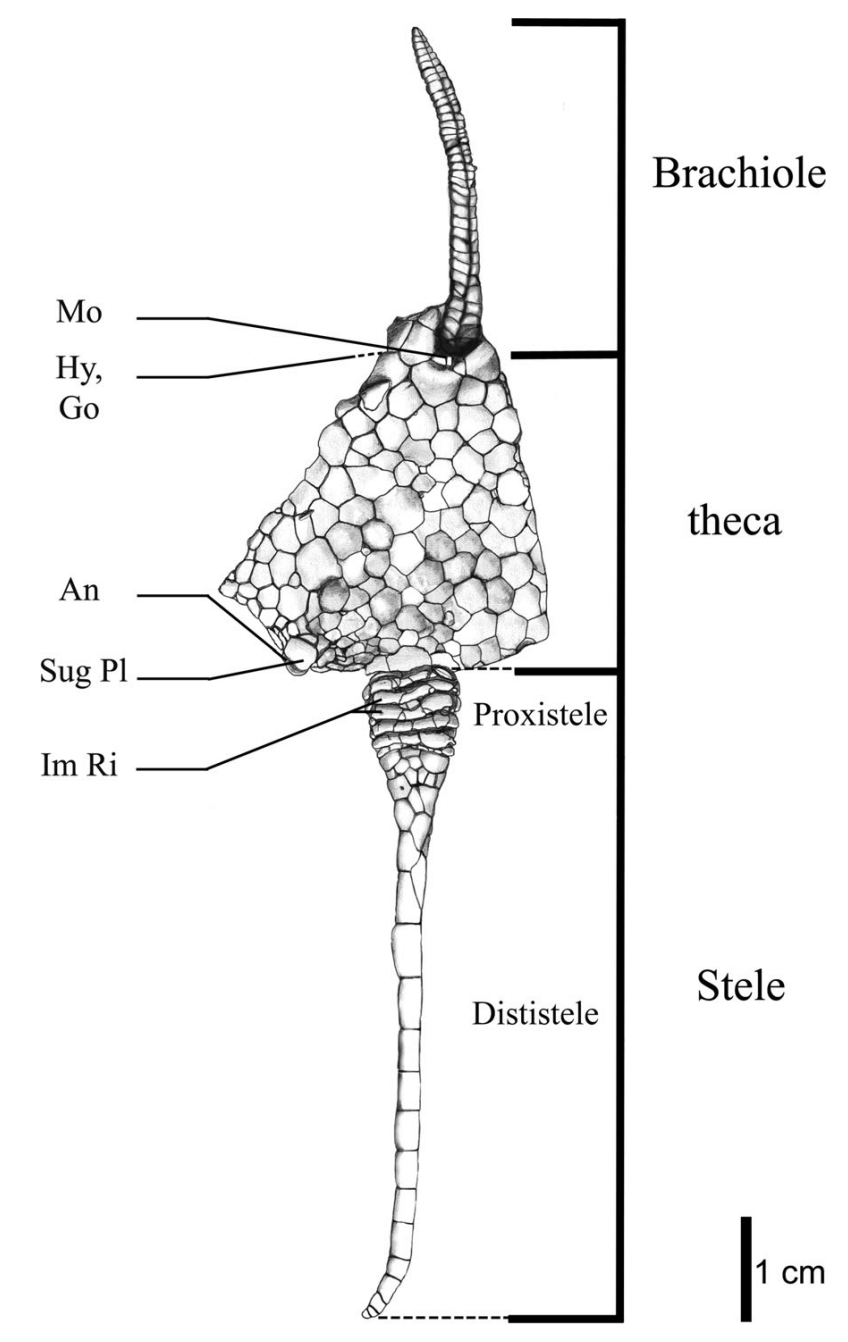

Figure 1. Morphology of Dendrocystites barrandei Bather, 1913; reconstitution based on the lower surface of specimen CGS.6047, Letná Formation (Sandbian), Prague Basin (Czech Republic). An - anal opening, Go - gonopore, Hy - hydropore, Im $\mathrm{Ri}$ - pair of tetramerous rings, Mo - internal mouth, Sug Pl - sugar-loaf plate.

the main thecal opening corresponds to a small slit-like orifice located at the summit of a low, modified valvular pyramid, consisting of several elongate, radial platelets and two enlarged, cone-shaped elements ("sugar-loaf plates"; Bather 1913, Caster 1967, Jell \& Holloway 1982, Jefferies 1990, Daley 1992, Rozhnov \& Jefferies 1996, Parsley et al. 2012, Rahman \& Lintz 2012). In some other solutans (e.g., Belemnocystites, Iowacystis, Myeinocystites, Scalenocystites), radial platelets are lost, and the main body orifice consists in a narrow slit in between two particularly enlarged "marginal" plates forming a clam shell door-like structure (Caster 1967, Parsley 1972, Kolata 1973, Kolata et al. 1977). In Dendrocystites (Fig. 1), the main thecal opening is covered by a single, large sugar-loaf plate, forming an outlet valve, which articulates to an underlying, rounded lappet (see Barrande 1887, pl. 26, figs 6, 14, 16; 
Bather 1913, Caster 1967). Comparison with similar structures occurring in many groups of echinoderms suggests that the cone-shaped pyramid of primitive solutans corresponds to the periproct, and its associated orifice to the anal opening (Caster 1967; Ubaghs 1970; Ubaghs \& Robison 1985; Daley 1995, 1996; David et al. 2000; Prokop \& Petr 2003; Smith 2005; Lefebvre et al. 2012). This identification implies that the slit-like orifice of more derived taxa (e.g., Dendrocystites, Iowacystis, Maennilia, Scalenocystites) also corresponds to the anus (Bather 1913, Parsley \& Caster 1965, Caster 1967, Parsley 1972, Kolata 1973, Kolata et al. 1977, Rozhnov \& Jefferies 1996, Parsley et al. 2012). This interpretation of the slit-like orifice is supported by its morphology (clearly designed as a vent), and its position (identical to that of the anus in other solutans). The associated highly derived periproctal morphologies (e.g., anus sheltered by a single, articulated outlet valve, or by two large, opposable plates forming a clam shell doorlike structure) have no direct equivalent in echinoderms, with the possible exceptions of the cinctan operculum (Jaekel 1918, Ubaghs 1967c, Parsley 1999) and the subanal plate occurring in some mitrates (Chinianocarpos, Jaekelocarpus, Kirkocystidae; Ubaghs 1970, Lefebvre 2001).

\section{Brachiole}

The short appendage of Dendrocystites was initially interpreted by Barrande (1887) as a putative "tubus ventralis", equivalent in morphology to the anal tube of crinoids. This interpretation was rejected by Neumayr (1889), who suggested that the short appendage of solutans was more likely a feeding structure. Since Neumayr (1889), a feeding function for the short solutan appendage is universally accepted (Haeckel 1896, Bather 1913, Jaekel 1918, Thomas \& Ladd 1926, Thoral 1935, Caster 1967, Ubaghs 1970, Nichols 1972, Kolata et al. 1977, Philip 1979, Jefferies 1990, Daley 1992, David et al. 2000, Smith 2005, Lefebvre et al. 2012, Parsley et al. 2012, Rahman \& Lintz 2012, Rozhnov 2012). Contrary to Bather's reconstruction of Dendrocystoides scoticus (1913, fig. 9), the transition between the solutan feeding appendage and the theca is not gradual, but always sharp (Caster 1967, Jefferies 1990). Both the hydropore and gonopore are located close to the insertion of the feeding appendage into the theca (see above).

In many solutans (e.g., Coleicarpus, Dendrocystites, Heckericystis), the feeding appendage and the homoiostele are inserted at opposite extremities of the theca (Barrande 1887, Bather 1913, Gill \& Caster 1960, Caster 1967, Daley 1996). However, in several taxa, the insertion of the feeding process is not apical, but displaced laterally and posteriorly, either along the anal margin of the theca (e.g., Dendrocystoides, Girvanicystis, Maennilia; Bather 1913,
Jefferies 1990, Daley 1992, Rozhnov \& Jefferies 1996, Parsley et al. 2012), or along the opposite, antanal thecal margin (Minervaecystis; Ubaghs 1970). Finally, in some other solutans (e.g., Belemnocystites, Iowacystis, Myeinocystites, Scalenocystites), the insertion of the feeding appendage is also not in apical position, but displaced posteriorly on the plano-concave thecal surface (Thomas \& Ladd 1926, Bather 1928, Parsley \& Caster 1965, Parsley 1972, Kolata 1973, Kolata et al. 1977).

The solutan feeding appendage is highly flexible, distally tapering, and typically made of two unequal series of paired, alternating skeletal elements: two longitudinal rows of large flooring plates, and two longitudinal rows of smaller cover plates (Bather 1913; Caster 1967; Ubaghs \& Robison 1985; Daley 1992, 1995, 1996; David et al. 2000; Smith 2005). In most taxa (e.g., Castericystis, Girvanicystis, Iowacystis, Minervaecystis), each cover plate is in contact with a single flooring plate (Caster 1967, Ubaghs 1970, Ubaghs \& Robison 1985, Daley 1992, Kolata et al. 1977). In these forms, the feeding appendage thus consists in a longitudinal series of basically tetramerous, transverse rings. In some other solutans (e.g., Dendrocystoides), the left and right series of cover plates are more numerous and without any correspondence with the two rows of associated flooring plates (Jefferies 1990). In both series of paired skeletal elements, new plates were apparently added during ontogeny at the distal tip of the short appendage, alternatively on the right and on the left (Ubaghs \& Robison 1985, Daley 1996, Rozhnov \& Jefferies 1996, Rozhnov 2002). The two biseries of plates delimit a small central lumen, which was probably communicating with the main body cavity through an unobserved orifice (the mouth), presumably located at the contact between the short appendage and the theca (Neumayr 1889, Bather 1913, Caster 1967, Ubaghs 1970, Kolata et al. 1977, Philip 1979, Ubaghs \& Robison 1985, Jefferies 1990, Daley 1992, David et al. 2000, Smith 2005). An alternative location of the mouth, at the distal extremity of the solutan feeding appendage was proposed by Haeckel (1896). This interpretation of the short solutan process as a proboscis-like structure was refuted by Bather (1913), because of the absence of any orifice at the distal tip of the appendage (see also Caster 1967).

In most solutans (e.g., Castericystis, Dehmicystis, Iowacystis, Scalenocystites), the two rows of flooring plates display a clear alternating pattern, with left and right elements separated by an obvious zigzag suture (Parsley \& Caster 1965, Caster 1967, Kolata 1973, Kolata et al. 1977 , Ubaghs \& Robison 1985, Daley 1995, Rahman \& Lintz 2012). In some taxa (e.g., Maennilia), flooring plates are clearly alternating in the distal-most part of the feeding appendage, but are almost opposite to each other more proximally (Rozhnov \& Jefferies 1996). In some other solutans (e.g., Dendrocystoides, Syringocrinus), flooring plates are 
not alternating: they are opposite to each other, and thus, separated by a straight suture (Parsley \& Caster 1965, Jefferies 1990). Finally, in several taxa (e.g., Coleicarpus, Dendrocystites, Minervaecystis, Myeinocystites), some specimens are apparently characterized by the presence of a single series of flooring plates (Bather 1913, Caster 1967, Ubaghs 1970, Parsley 1972, Daley 1996). This uniserial arrangement can occur along a significant portion, or the total length of the feeding appendage. In most solutans (e.g., Castericystis, Dehmicystis, Dendrocystoides, Iowacystis, Scalenocystites), flooring plates of a same longitudinal row are typically imbricate, and partially overlap their more distal neighbour (Caster 1967, Kolata et al. 1977, Ubaghs \& Robison 1985, Jefferies 1990, Daley 1995, Rahman \& Lintz 2012). However, other solutans (e.g., Girvanicystis) apparently do not show any evidence of such an imbrication (Daley 1992).

In all solutans, the two opposite rows of left and right cover plates are also clearly alternating, and are thus separated by an obvious zigzag contact (Bather 1913; Parsley \& Caster 1965; Caster 1967; Kolata 1973; Kolata et al. 1977; Ubaghs \& Robison 1985; Daley 1995, 1996). Although they have been seldom - if ever - observed in open position, most authors consider that the two sets of cover plates were not sutured in life, but were very likely erectile (Ubaghs 1970; Parsley \& Caster 1965; Caster 1967; Parsley 1972; Kolata et al. 1977; Jefferies 1990; Daley 1992, 1995, 1996). As for their associated flooring plates (see above), cover plates belonging to a same longitudinal row often display an imbricate pattern, and partially overlap distally the proximal portion of their immediate neighbour, as for example, in Castericystis (Ubaghs \& Robison 1985). However, the feeding appendage of some solutans (e.g., Dendrocystoides) does not show any clear evidence of such an imbrication pattern for the cover plates (Jefferies 1990).

Following Neumayr (1889), the feeding appendage of solutans is frequently described as an "arm", because of its stout, massive aspect (Thomas \& Ladd 1926; Thoral 1935; Caster 1967; Ubaghs 1970; Nichols 1972; Parsley 1972; Kolata 1973; Kolata et al. 1977; Ubaghs \& Robison 1985, 1988; Jefferies 1990; Daley 1992, 1995, 1996; Sprinkle 1992; Rozhnov \& Jefferies 1996; Rozhnov 2002, 2012; Prokop \& Petr 2003; Smith 2005). However, the two biseries of skeletal elements forming the feeding appendage of solutans are regularly produced, during ontogeny, alternatively on the right and on the left, at the distal extremity of the appendage (see above). The resulting staggered, generally alternating plate pattern is typical of echinoderm ambulacral rays and of the Ocular Plate Rule (Mooi et al. 1994, David et al. 2000, Sprinkle \& Guensburg 2001). This observation suggests that all skeletal elements belonging to the feeding appendage of solutans (i.e. both flooring and cover plates) are very likely ambulacral (axial) elements (David et al. 2000, Peterson et al. 2000, Nardin et al. 2009). Consequently, the feeding appendage of solutans cannot be interpreted as an arm-like structure, because echinoderm arms are extensions of the body wall (and associated coeloms) including both ambulacral (axial) and thecal (extraxial) skeletal elements (e.g., asterozoan and crinoid arms; David et al. 2000, Hotchkiss 2012). Following Bather (1900, 1913, 1928), the feeding appendage of solutans is interpreted herein as a free portion of ambulacrum, i.e. as a brachiole (Zittel 1903, Dehm 1934, Regnéll 1945, Termier \& Termier 1948, Cuénot 1953, Gill \& Caster 1960, Nichols 1962, Philip 1979, Parsley 1997, Allasinaz 1999, David et al. 2000, Peterson et al. 2000, Lefebvre \& Fatka 2003, Sprinkle \& Guensburg 2004, Parsley \& Sumrall 2007, Martí Mus 2009, Nardin et al. 2009, Lefebvre et al. 2012, Rahman \& Lintz 2012). The possession of a single, robust brachiole is not unique to solutans, but is also documented in the highly derived pleurocystitid rhombiferans Fusicystis magnificus (Upper Ordovician of Russia; Zuykov et al. 2008) and Hillocystis atracta (Early Devonian of Australia; Jell 1983).

\section{Homoiostele}

In solutans, the theca/homoiostele boundary is always sharp, without any gradual transition. The homoiostele is generally inserted in the posterior lateral wall of the theca, close to the anal opening (Bather 1913, Parsley \& Caster 1965, Caster 1967). However, a different pattern was documented by Lefebvre et al. (2012) in a solutan indet. from the Šárka Formation of Bohemia: its homoiostele insertion is not located in a marginal position, but more anteriorly, on the same plano-concave thecal surface as the feeding appendage.

In the most primitive known solutan (Coleicarpus), the homoiostele is entirely made of abundant, unorganized, imbricate, scale-like platelets (Daley 1996). In Coleicarpus, this appendage forms a long tube-like structure, regularly tapering in a distal direction, and enclosing a wide central lumen. Both juvenile and adult individuals of Coleicarpus were apparently permanently attached to the sea-floor and/or to any available, rigid surface (i.e., trilobite fragments, other solutans) by the sucker-like distal extremity of their homoiostele (Daley 1996). In the other mid Cambrian primitive solutan, Castericystis, only juvenile specimens were attached to various objects by the tip of their homoiostele (Ubaghs \& Robison 1985, Daley 1995). In all more derived solutans, both juvenile and adult stages were apparently free-living and unattached (Gill \& Caster 1960, Ubaghs 1970, Daley 1992, David et al. 2000, Smith 2005). In all solutans (but the most primitive form, Coleicarpus), the homoiostele is divided into two distinct regions: a highly flexible proximal part ("proxistele"), and 
a much more rigid distal portion ("dististele"; Bather 1913, Thoral 1935, Gill \& Caster 1960, Caster 1967, Ubaghs 1981, Jefferies 1990, David et al. 2000, Smith 2005).

In some solutans (e.g., Castericystis, Plasiacystis), the proxistele is relatively long, and entirely made of numerous, unorganized, imbricate, scale-like elements (Ubaghs \& Robison 1985, Daley 1995, Lefebvre et al. 2012). However, in most taxa (e.g., Claritacarpus, Dehmicystis, Dendrocystites, Girvanicystis, Heckericystis, Iowacystis, Minervaecystis, Rutroclypeus), the proxistele is short, and consists in several telescopic, transverse, tetrameric rings (Bather 1913, Thoral 1935, Gill \& Caster 1960, Parsley \& Caster 1965, Caster 1967, Ubaghs 1970, Parsley 1972, Kolata 1973, Kolata et al. 1977, Daley 1992, Parsley \& Sumrall 2007, Rahman \& Lintz 2012). Each ring is almost bilaterally symmetrical, and made of two pairs of closely associated elements. In several solutans, scale-like integumentary platelets are intercalated in between successive tetrameric proximal rings (e.g., Dendrocystites, Dendrocystoides; Bather 1913, Caster 1967, Jefferies 1990). The proximal part of the appendage encloses a large, central lumen. Proximally, this lumen was connected to the main intrathecal cavity by a wide, internal, sub-circular orifice (see Parsley 1972, pl. 1, fig. 3; Ubaghs 1981).

In most solutans, the dististele is longer than the proxistele. In several taxa (e.g., Castericystis, Iowacystis, Minervaecystis, Scalenocystites, Syringocrinus), the distal region consists in a distally tapering, flattened, elongate structure, made of two longitudinal rows of tightly sutured, large skeletal elements (left and right series), separated by numerous, unorganized platelets (Thomas \& Ladd 1926, Parsley \& Caster 1965, Caster 1967, Ubaghs 1970, Kolata 1973, Kolata et al. 1977, Ubaghs \& Robison 1985, Daley 1995). In these solutans, the dististele is often ornamented with lateral spines (e.g., Castericystis, Scalenocystites), serrations (e.g., Syringocrinus), or comb-like (pectinate) protuberances (e.g., Minervaecystis). Moreover, one lateral margin of this part of the long appendage is often rounded and inflated, whereas the opposite margin forms a sharp keel (e.g., Castericystis, Syringocrinus). In Plasiacystis, the distal region of the long appendage is also strongly flattened, keeled, ornamented (protuberances), and made of two series (left and right) of large plates separated by a zigzag suture and some intercalary platelets, but it is modified into a short and wide paddle-like structure, with a large, rounded, distal extremity (Prokop \& Petr 2003, Lefebvre et al. 2012). Finally, in some other solutans (e.g., Claritacarpus, Dehmicystis, Dendrocystites, Dendrocystoides, Girvanicystis, Maennilia), the distal part of the long appendage forms a long, almost cylindrical, distally tapering structure, frequently with a recurved, hook-like distal extremity (Bather 1913, Caster 1967, Jefferies 1990, Daley 1992, Rozhnov \& Jefferies 1996, Parsley \& Sumrall 2007, Parsley et al. 2012, Rahman \&
Lintz 2012). In these forms, the distal region is made of two longitudinal rows (upper and lower series) of tightly sutured skeletal elements. In all solutans, the dististele totally encloses a small lumen, which communicates, proximally, with the larger cavity of the proxistele (Gill \& Caster 1960; Ubaghs 1970, 1981; Kolata et al. 1977; Ubaghs \& Robison 1985; Jefferies 1990; Daley 1992). The lumen of the dististele can be either in a lateral (e.g., Castericystis, Minervaecystis, Plasiacystis) or in a central position (e.g., Dendrocystites, Girvanicystis).

The homoiostele of Coleicarpus corresponds to a stalk-like structure, comparable in morphology to the polyplated stalks of many Cambrian eocrinoids (e.g., Gogia, Nolichukia). In contrast, the homoiostele of all more derived solutans (e.g., Dendrocystites, Iowacystis) represents a stem-like structure: it is elongate, highly organized, multimeric (e.g., tetraserial proximal rings), and it encloses a small lumen. Consequently, the almost perfect bilateral symmetry exhibited by the homoiostele of many solutans represents a derived condition. It results from the standardization of an initially polyplated or radially symmetrical stalk-like appendage equivalent in morphology to that of many primitive eocrinoids (plesiomorphic condition, as in the mid-Cambrian solutan Coleicarpus). Moreover, the occurrence of two distinct plate patterns in the dististele, with either left and right series of large skeletal elements (e.g., Castericystis, Iowacystis, Minervaecystis, Plasiacystis) or lower and upper series of plates (e.g., Claritacarpus, Dendrocystites, Girvanicystis, Maennilia) suggests that the standardization of the dististele was possibly achieved independently within two distinct lineages of solutans (see discussion below).

\section{Geological setting}

The Prague Basin is a narrow, deep sedimentary basin, probably of rift origin, extending longitudinally from Plzeň in the SW to Prague in the NE (Fig. 2A, B), and striking at about $20^{\circ}$ to the Cambrian Príbram-Jince Basin (Chlupác 1993, Štorch et al. 1993). In Late Ordovician times, the Prague Basin was located at relatively high palaeolatitudes, close to the Gondwanan palaeocontinent (Fatka \& Mergl 2009, Servais \& Sintubin 2009). The Upper Ordovician succession is particularly thick, and comprises mainly volcano-clastic and siliciclastic sediments (Havlíček \& Vaněk 1966, Štorch et al. 1993). It is stratigraphically subdivided into seven formations (Fig. 2C), from bottom to top: Libeň, Letná, Vinice (Sandbian), Zahořany, Bohdalec, Králův Dvůr (Katian), and Kosov (Hirnantian). The Upper Ordovician deposits of the Prague Basin have yielded extremely abundant and diverse assemblages of marine invertebrates (e.g., arthropods, brachiopods, bryozoans, conulariids, echinoderms, graptolites, molluscs), exhibiting 


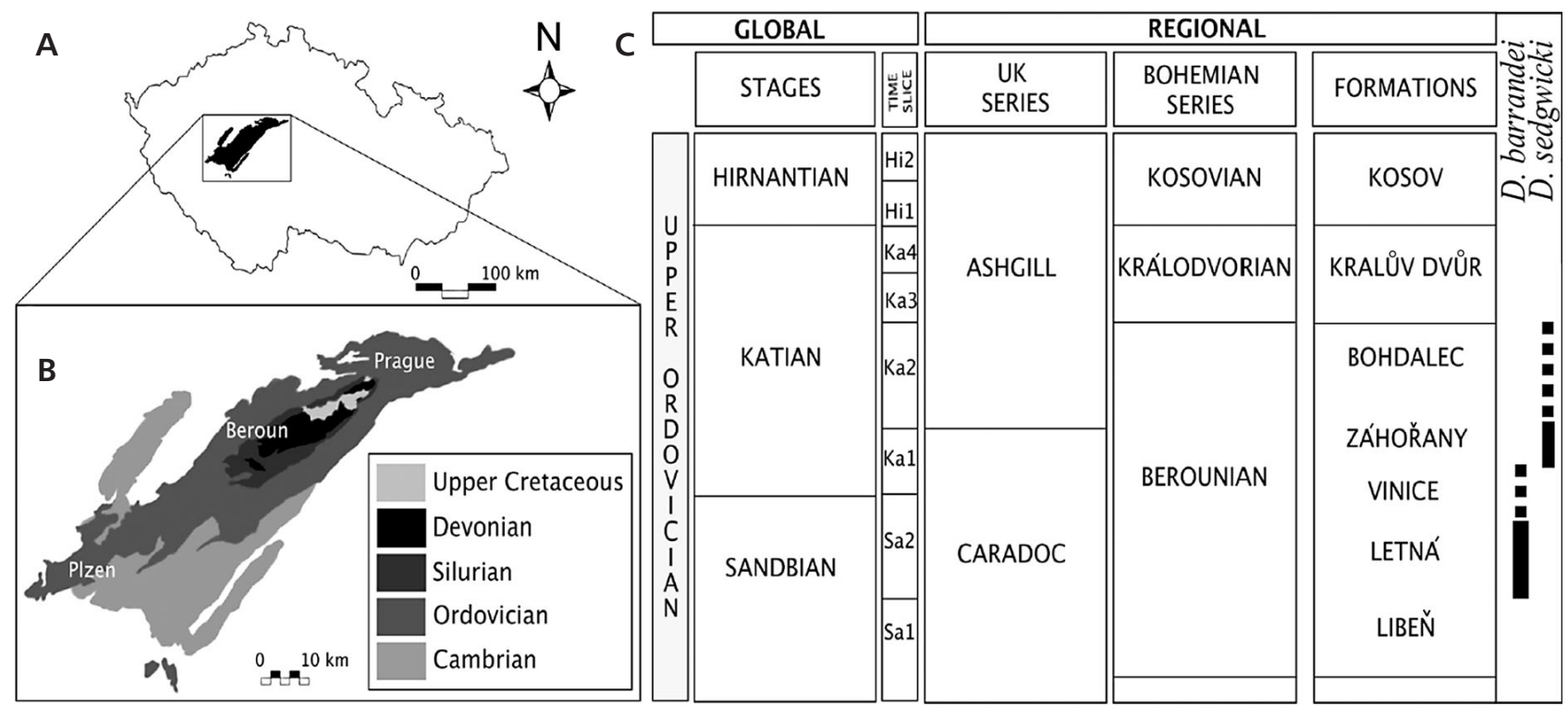

Figure 2. A - generalized map of the Czech Republic showing the Prague Basin. $\bullet$ B - sketch map of the Prague Basin showing the Ordovician outcrops (modified from Drost et al. 2011). • C - stratigraphic chart of the Ordovician of the Prague Basin (modified from Fatka et al. 2013).

clear affinities with faunas from other regions of the Mediterranean Province (e.g., Brittany, Morocco, Spain; Havlíček \& Vaněk 1966; Havlíček 1982, 1989; Havlíček \& Fatka 1992; Gutiérrez-Marco et al. 1999; Lefebvre et al. 2010). In the Prague Basin, Dendrocystites was collected in the four successive formations of Letná, Vinice, Zahořany, and Bohdalec. Specimens are particularly abundant in the two formations of Letná and Zahořany, and extremely rare in the deposits of both Vinice and Bohdalec formations.

The Letná Formation is a particularly thick lithostratigraphic unit (40-600 m), consisting mainly of sandstones alternating with finer sediments (Havlíček 1982, Fatka et al. 2013). This unit has yielded particularly rich and diverse echinoderm assemblages, comprising the aristocystitid diploporan Aristocystites cf. bohemicus, various edrioasteroids, the eocrinoid Ascocystites drabowensis, the rhombiferans Echinosphaerites infaustus, Macrocystella bohemica and Rhombifera bohemica (Barrande 1887), the crinoid Caleidocrinus multiramus (Waagen \& Jahn 1899), the mitrate stylophorans Anatifopsis spinosa, Aspidocarpus bohemicus, and Barrandeocarpus jaekeli (Ubaghs 1979), the paracrinoid Letenocrinus longibrachialis (Prokop \& Petr 1990), and various asteroids (Prokop \& Petr 1999). Recent field work and the reexamination of historical collections (Czech Geological Survey, Prague and Museum für Naturkunde, Berlin) both indicate the presence of additional, yet undescribed echinoderm taxa in the Letná Formation: the diploporan Hippocystis sp. and the cornute stylophoran Scotiaecystis sp. (L. Kašička, pers. obs.), as well as two new species of mitrate stylophorans (an Eumitro- cystella-like basal paranacystid and an Enoploura-like anomalocystitid; B. Lefebvre, pers. obs.). Dendrocystites occurs massively in the uppermost part of the Letná Formation, within the fine-grained greywackes of the Bicuspina Community (Havlíček 1982). In these levels, dense assemblages of Dendrocystites are frequently associated with brachiopods (e.g., Bicuspina cava) and the echinoderms Echinosphaerites infaustus, Macrocystella bohemica, Rhombifera bohemica, and Scotiaecystis sp. (Havlíček 1982; L. Kašička, pers. obs.). The two localities of Háj and Trubská have yielded all the specimens of Dendrocystites sedgwicki from the Letná Formation figured by Barrande (1887, pl. 27, figs 5, 19-23). All these specimens were assigned by Bather (1913) to a distinct species, D. barrandei. Consequently, the two localities of Háj and Trubská were designated as type-localities of $D$. barrandei by Bather (1913).

The Vinice Formation (20-450 m) is characterized by finer-grained siliclastic deposits (shales and silty shales) probably resulting from a deepening of the Prague Basin (Havlíček 1982, Štorch et al. 1993). At the base of the Vinice Formation, a well-defined horizon of sedimentary iron ore has yielded a diverse echinoderm assemblage (Havlíček 1982, Havlíček \& Fatka 1992). This assemblage is dominated by blastozoans (Aristocystites, Echinosphaerites, Fungocystites, Heliocrinites, Hippocystis, Mespilocystites, Rhombifera; Barrande 1887), associated with kirkocystid mitrates ("Spermacystis" ensifer is a kirkocystid; Barrande 1872, 1887; Ubaghs 1967b) and undescribed remains of crinoids (Prokop \& Petr 1999). Recent field work in the Vinice Formation has yielded numerous specimens of previously unreported taxa of 
echinoderms (L. Kašička, pers. obs.): the eocrinoid Ascocystites sp., the cornute Scotiaecystis sp., as well as various mitrocystitid mitrates (e.g., Aspidocarpus, Barrandeocarpus, Diamphidiocystis). All specimens of Dendrocystites were also collected in this iron ore horizon at the base of the Vinice Formation. Three specimens of Dendrocystites were reported by Barrande (1887, pl. 27, figs 1, 17-18) from his bande d3, at the locality of Trubin. However, Perner (in Bather 1913, p. 388) suggested that only one original specimen of Barrande (1887, pl. 27, fig. 18) could be confidently identified as actually coming from the Vinice Formation. This specimen was assigned to D. sedgwicki by Bather (1913). Another specimen of Dendrocystites was collected recently in the field, thus confirming the presence of this genus in the Vinice Formation (L. Kašička, pers. obs.).

The Zahořany Formation is a thick lithostratigraphic unit (70-400 m) composed mainly of siltstones with rare intercalations of silty shales and fine-grained sandstones (Havlíček 1982, Havlíček \& Fatka 1992). The occurrence of hummocky cross stratification and of abundant trace fossils belonging to the Zoophycos ichnofacies are both suggestive of shallower environmental conditions than in the underlying Vinice Formation (Štorch et al. 1993, Mikuláš 1999). The fine-grained sandstones of the Zahořany Formation have yielded a diverse echinoderm assemblage dominated by blastozoans (Aristocystites, Calix, Cardiocystites, Codiacystis, Echinosphaerites, Fungocystites, Hippocystis, Homocystites, Mespilocystites, Rhombifera; Barrande 1887; Parsley 1990, 1998; Prokop \& Petr 1999), associated with asteroids (Jaekel 1903), edrioasteroids (Barrande 1887), ophiuroids (Bohemura jahni; Petr 1989a), and rare crinoids (Polycrinus ramulatus; Jaekel 1918, Prokop 1984) and mitrates (Barrande 1872, 1887). In the Zahořany Formation, Dendrocystites occurs massively in some levels of greywackes characterized by low-diversity assemblages comprising mostly infaunal ophiuroids (Bohemura jahni), stemmed blastozoans (Echinosphaerites infaustus), and conulariids (Petr 1989a). Other faunal elements (e.g., trilobites) are usually rare or absent in such horizons. Dendrocystites sedgwicki was initially reported by Barrande (1867) at the locality of Zahořany, in micaceous siltstones of the Zahořany Formation, and most of his figured specimens are from this locality (Barrande 1887, pl. 26, figs 1-22, pl. 27, figs 2-4, 6-16). All specimens of Dendrocystites collected in the Zahořany Formation were identified as D. sedgwicki by Bather (1913), and Zahořany was defined as type-locality for this species. However, the examination of the abundant material of Dendrocystites available in both public and private collections indicates that not only large $D$. sedgwicki-like specimens occur in the Zahořany Formation, but also small D. barrandei-like ones, as well as specimens of Dendrocystites intermediate both in size and in morphology between $D$. barrandei and $D$. sedgwicki (see discussion below).

The Bohdalec Formation is a relatively thick and monotonous lithostratigraphic unit (20-500 m) consisting mostly of black shales, with some interbedded levels of siltstones and fine-grained sandstones (Havlíček 1982, Havlíček \& Fatka 1992, Storch et al. 1993). In the Bohdalec Formation, echinoderm assemblages are less diverse than in the three underlying formations. They are dominated by crinoids (e.g., Caleidocrinus; Waagen \& Jahn 1899, Havlíček 1982), associated with asteroids (Prokop \& Petr 1999), blastozoans (Aristocystites, Echinosphaerites; Barrande 1887, Parsley 1990), and ophiuroids (Klarasterina klara, Taeniaster bohemicus; Petr 1989b, Mikuláš et al. 1995). During recent field work, one poorly preserved specimen of Dendrocystites was collected in the Bohdalec Formation (L. Kašička, pers. obs.), thus extending the stratigraphic range of the genus into the late Berounian.

\section{Material and methods}

This study is based primarily on the observation of more than 300 specimens of Dendrocystites from the Upper Ordovician of Bohemia deposited in several private collections and also in the following public institutions: Natural History Museum, London (BMNH), Czech Geological Survey, Prague (CGS), Naturhistoriska riksmuseet, Stockholm (EC), Université Lyon 1, Villeurbanne (FSL), Museum für Naturkunde, Berlin (MB), National Museum, Prague (NMP), and Naturhistorisches Museum, Vienna (NMW). More than 50 additional specimens of Dendrocystites from the Upper Ordovician of Morocco and Spain were also examined for comparison purposes. This material is deposited in the following public collections: Université Cadi Ayyad, Marrakech (AA), Université Lyon 1, Villeurbanne (FSL), Muséum d'Histoire naturelle, Marseille (MHNM), Muséum d'Histoire naturelle, Toulouse (MHNT), Musée des Confluences, Lyon (ML), and Museo Paleontológico de la Universidad de Zaragoza (MPZ). Finally, additional comparative material comprising both original specimens (Castericystis vali, Coleicarpus sprinklei, Dendrocystoides scoticus, Girvanicystis batheri, Minervaecystis vidali, Plasiacystis mobilis) and casts of type specimens (Iowacystis sagittaria, Myeinocystites crossmani, Scalenocystites strimplei) was also examined in the collections of the Natural History Museum, London (BMNH) and Université Lyon 1, Villeurbanne (FSL).

Specimens of Dendrocystites are typically preserved as hollow (negative) moulds, because of the dissolution of their original calcite skeleton. Consequently, latex casts were made so as to reproduce the original (positive) aspect of the specimens. Some of these latex peels were re-casted with polyurethane at the Paleolab of Bristol University. 
Casts were then coated either with ammonium chloride $\left(\mathrm{NH}_{4} \mathrm{Cl}\right)$ or magnesium oxide $(\mathrm{MgO})$, for both photographic and drawing purposes (camera-lucida mounted on a binocular microscope Leica MZ125Z).

\section{Systematic palaeontology}

Phylum Echinodermata Bruguière, 1791 (ex Klein, 1734) Subphylum Blastozoa Sprinkle, 1973

Discussion. - Solutans were sometimes identified as crustaceans (Withers 1933), or interpreted as hemichordatelike, primitive chordates (Jefferies 1990; Daley 1992, 1995, 1996; Benton 1993; Rozhnov \& Jefferies 1996; Rozhnov 2002). However, echinoderm affinities were more generally suggested for these fossils. Within echinoderms, solutans were sometimes erroneously identified as crinoids (Billings 1859, Wachsmuth \& Springer 1881) but, following Barrande $(1867,1887)$ they were generally interpreted as "cystoids" or blastozoans (Wetherby 1881, Neumayr 1889, Miller \& Gurley 1894, Haeckel 1896, Zittel 1903, Bather 1913, Thomas \& Ladd 1926, Dehm 1934, Thoral 1935, Bassler \& Moodey 1943, Moret 1958, Easton 1960, Parsley 1997, Sumrall 1997, Dzik 1999, David et al. 2000, Lefebvre \& Fatka 2003, Sprinkle \& Guensburg 2004, Kácha \& Šarič 2009, Nardin et al. 2009). Alternatively, solutans were also frequently allied with other flatfish, asymmetrical echinoderms within the homalozoans or "carpoids" (Jaekel 1918, Regnéll 1945, Termier \& Termier 1948, Cuénot 1953, Gill \& Caster 1960, Nichols 1962, Parsley \& Caster 1965, Ubaghs 1970, Kolata et al. 1977, Ubaghs \& Robison 1985, Sprinkle \& Kier 1987, Allasinaz 1999, Smith 2005). Solutans are considered herein as derived blastozoans (Sumrall 1997, David et al. 2000, Sprinkle \& Guensburg 2004, Nardin et al. 2009) rather than as basal, hemichordate-like echinoderms (Smith 2005, 2008).

\section{Class Soluta Jaekel, 1901}

Discussion. - In the last 50 years, solutans were generally assigned to the order Soluta Jaekel, 1901 within the class Homoiostelea Gill \& Caster, 1960 (Caster 1967; Ubaghs 1970; Nichols 1972; Parsley 1972, 1997; Kolata 1973; Kolata et al. 1977; Ubaghs \& Robison 1985, 1988; Sprinkle 1992; Sumrall et al. 1997, 2012; Allasinaz 1999; David et al. 2000; Rozhnov 2002; Prokop \& Petr 2003; Parsley \& Sumrall 2007; Parsley et al. 2012; Rahman \& Lintz 2012). As originally defined by Gill \& Caster (1960), the class Homoiostelea and its two subdivisions, the superorders Astylophora (order Soluta) and Stylophora (orders Cornuta and Mitrata) relied mainly on the supposedly similar aspect of the long appendage (stele) in these three groups of "carpoids". However, the homology of all homoiostelean steles was seriously questioned by Ubaghs (1963, 1967a, 1981), who removed the stylophorans from the homoiosteleans, and placed them in a separate class Stylophora. As a consequence, the class Homoiostelea was reduced to the single order Soluta, and the two taxonomic groups homoiosteleans and solutans became coextensive. The taxon name Homoiostelea is thus considered here as a junior, redundant synonym of Soluta and, following previous suggestions (e.g., Caster 1983, Daley 1992, Lefebvre et al. 2012), Soluta is retained as the valid class name.

The class Soluta Jaekel, 1901 is characterized by a low taxonomic diversity (18 genera described so far), a long stratigraphic range (mid Cambrian to Early Devonian), and a relatively wide morphological disparity within a same basic body plan (a polyplated theca with a single brachiole and a multimeric stem-like appendage). All new taxa were initially assigned to the single family Dendrocystidae Bather, 1899 (family name corrected into Dendrocystitidae Bassler, 1938; see below). However, in the last 50 years, repeated difficulties in identifying phylogenetic relationships between the taxa led to a dramatic increase in new family names: Iowacystidae and Rutroclypeidae (Gill \& Caster 1960), Syringocrinidae (Parsley \& Caster 1965), Belemnocystitidae, Girvanicystidae and Minervaecystidae (Caster 1967), Maennilidae (Rozhnov \& Jefferies 1996), and Plasiacystidae (Prokop \& Petr 2003). All these families are still considered as valid by most authors (e.g., Benton 1993), with the only exception of the family Belemnocystitidae, which was put in synonymy with the family Iowacystidae by Kolata et al. (1977). The only phylogenetic analysis completed so far on solutans confirms the monophyly of iowacystids, but leaves all other genera as a weakly resolved, paraphyletic assemblage between basal-most taxa (Coleicarpus, Castericystis) and iowacystids (Parsley 1997; see also Parsley \& Sumrall 2007, Parsley et al. 2012).

The detailed reexamination of solutan morphology (see above) suggests that the identification of relationships between solutan genera has been largely obscured by the wide morphological disparity displayed by the theca (e.g., almost half of the characters used in Parsley's 1997 phylogenetic analysis are based on the shape, the ornamentation and the plating of the theca). It is suggested here that two main solutan clades can be readily identified based primarily on the organization of their dististele and the morphology of their periproct, and possibly also on the location of their brachiole. The longitudinally undifferentiated stalklike homoiostele of Coleicarpus probably represents the plesiomorphic condition in solutans (Daley 1996, Parsley 1997, David et al. 2000, Smith 2005). It is proposed here that two morphologically distinct patterns of dististele organization were elaborated independently from the polyplated, undifferenciated stalk-like appendage of Coleicarpus. Consequently, a major subdivision of the class 

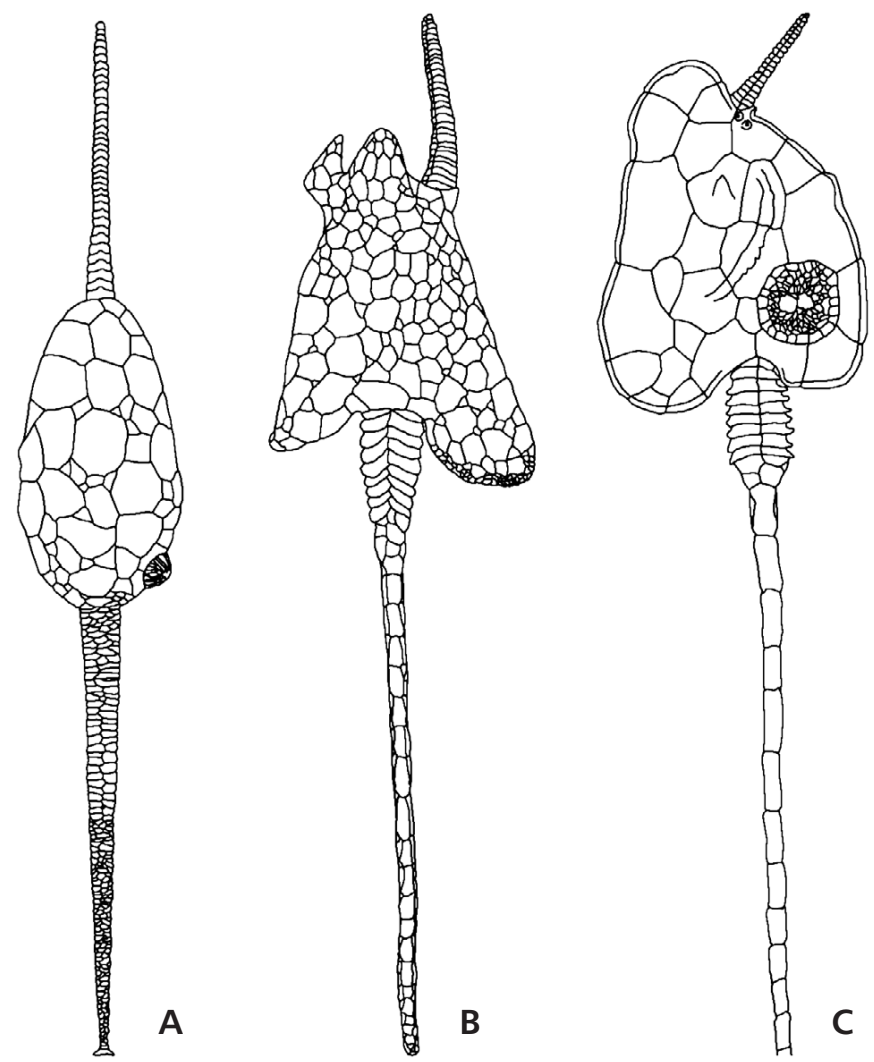

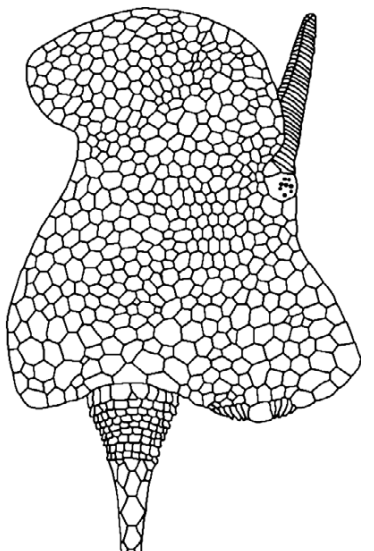

Figure 3. Solutan morphology: basal taxa (A) and Dendrocystitida (B-D), all in upper aspect. $\bullet$ A - Coleicarpus sprinklei, redrawn from Daley (1996). - B - Dendrocystitoides scoticus, redrawn from Jefferies (1990). • C Girvanicystis batheri, redrawn from Daley (1992). • D - Maennilia estonica, redrawn from Rozhnov \& Jefferies (1996).
Soluta into two main clades (the orders Dendrocystitida and Syringocrinida) is suggested below. The monophyly of each order is supported by apomorphies based primarily on the organization of the dististele and the morphology of the periproct. In this revised taxonomic scheme, Coleicarpus (Fig. 3A) is not assigned to any of the two solutan orders, as this genus very likely occupies a basal position within the class Soluta. A detailed phylogenetic analysis of all solutan taxa is beyond the scope of this paper, but is in preparation and will be presented elsewhere.

Order Syringocrinida (Parsley \& Caster, 1965) ord. nov.

Diagnosis. - An order of solutans with a multimeric homoiostele comprising a highly flexible proxistele and a rigid dististele. Particularly flattened and enlarged dististele, generally ornamented on one lateral side. Dististele made of two series (left and right) of skeletal elements, separated by a longitudinal zigzag suture and frequently, by irregular intercalary platelets. Periproct always located in lateral (marginal) position, close to homoiostele insertion. Anal opening located either at the summit of a large and high, cone-shaped, valvular pyramid or consisting of a narrow slit in between two enlarged marginal thecal plates forming a clam shell door-like structure. Single brachiole inserted either in apical position, or more posteriorly, along the antanal thecal margin and/or on the plano-concave thecal side.
Discussion. - Syringocrinus paradoxicus Billings, 1859, from the Upper Ordovician of Quebec, Canada is the type species of the family Syringocrinidae Parsley \& Caster, 1965 and the first solutan ever described showing an enlarged, flattened dististele (see Billings 1859, pl. 10, fig. 14; Bather 1913, 1928; Gill \& Caster 1960; Parsley \& Caster 1965; Caster 1967). The monogeneric family Syringocrinidae is here elevated to ordinal level, so as to include Castericystis vali plus all other solutans previously assigned to the families Iowacystidae (Belemnocystites, Iowacystis, Myeinocystites, Scalenocystites), Minervaecystidae (Minervaecystis), and Plasiacystidae (Plasiacystis) (Fig. 4). The enigmatic genus Drepanocystis, from the Lower Ordovician Wah Wah Limestone of Utah (Sumrall et al. 2012), is tentatively interpreted herein as a highly derived syringocrinid solutan. Within the order Syringocrinida, the family Iowacystidae is retained here as a valid taxonomic entity, corresponding to a well-defined clade of derived Late Ordovician Laurentian solutans. All other genera probably represent a paraphyletic assemblage of basal syringocrinids. The stratigraphic distribution of syringocrinid solutans is apparently restricted from the mid Cambrian (Castericystis) to the Late Ordovician (Iowacystidae, Syringocrinus). The late Cambrian isolated homoiosteles from Nevada figured by Ubaghs (1963) and Sumrall et al. (1997) clearly belong to syringocrinid solutans. 
Figure 4. Solutan morphology: Syringocrinida. All taxa in upper aspect. $\bullet \mathrm{A}-$ Castericystis vali, redrawn from Daley (1995). • B - Minervacystis vidali, redrawn and modified from Ubaghs (1970). $\bullet$ C - Plasiacystis mobilis, redrawn from Lefebvre et al. (2012). • D Iowacystis sagittaria, redrawn from Kolata et al. (1977).
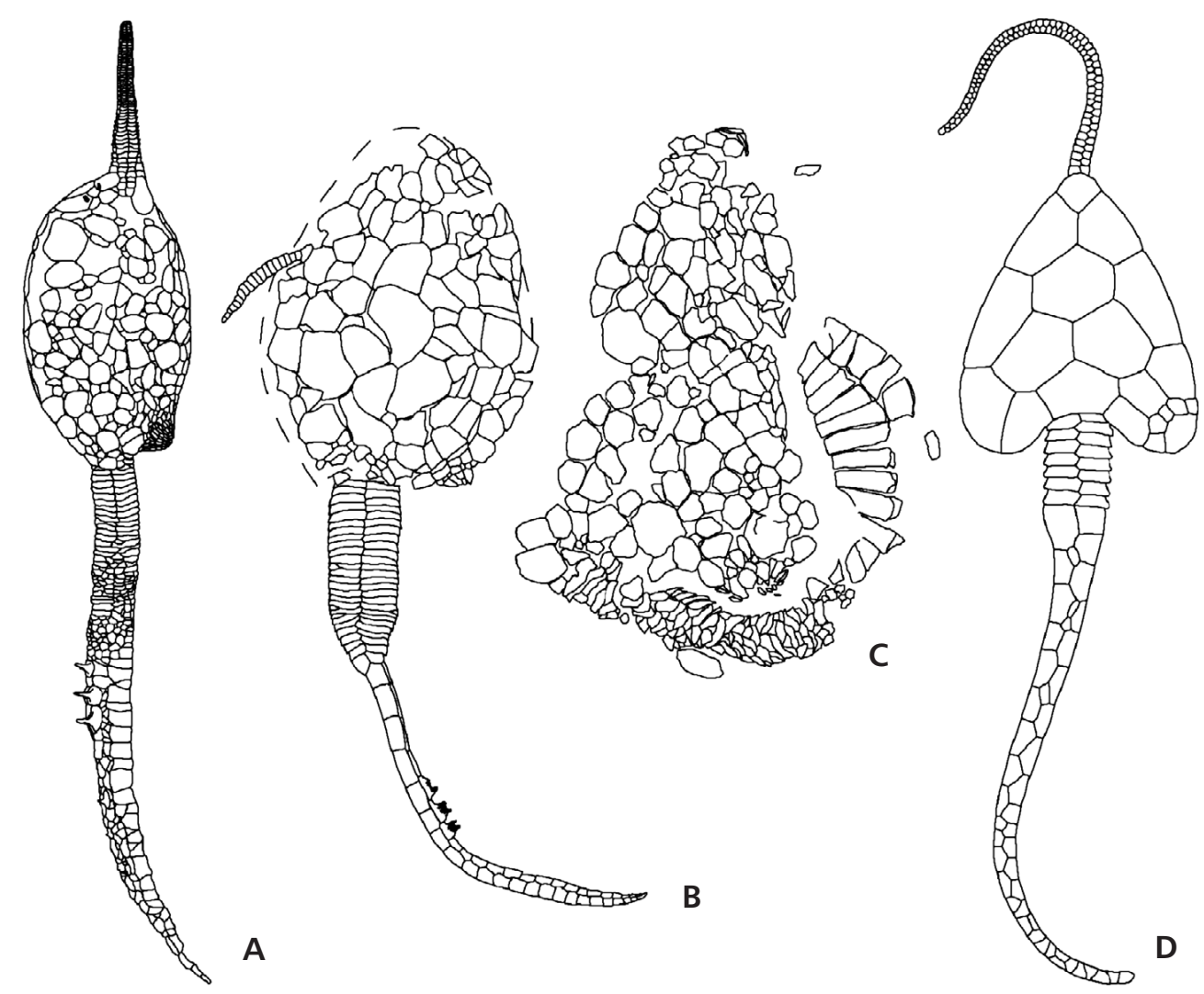

Order Dendrocystitida (Bassler, 1938) ord. nov.

Diagnosis. - An order of solutans with a multimeric homoiostele comprising a highly flexible proxistele and a rigid dististele. Elongate, narrow, cylindrical dististele without any lateral ornamentation. Dististele made of two series (upper and lower) of tightly sutured skeletal elements. Wide, extremely flat, circular periproct located either on convex thecal surface or in lateral (marginal) position, close to homoiostele insertion. Periproct frequently containing one or two enlarged, hemispherical suranal, "sugarloaf" plates. Single brachiole inserted either in apical position, or more posteriorly, along the anal thecal margin and/or on the plano-concave thecal side.

Discussion. - Dendrocystites sedgwicki (Barrande, 1867) from the Upper Ordovician of the Prague Basin, Czech Republic represents both the type species of the family Dendrocystitidae Bassler, 1938 and the first solutan ever described possessing an elongate, cylindrical dististele. The family Dendrocystitidae is here elevated to ordinal level, so as to include the solutan indet. from the Šarka Formation described by Lefebvre et al. (2012), plus all genera previously assigned to the four families Dendrocystitidae, Girvanicystidae, Maennilidae and Rutroclypeidae (i.e., Claritacarpus, Dehmicystis, Dendrocystites, Dendrocystoides, Girvanicystis, Heckericystis, Maennilia and Rutro- clypeus) (Fig. 3B-D). The dististele of the Darriwilian solutan indet. from Bohemia shows the typical organization of dendrocystitid solutans (see Lefebvre et al. 2012, figs 6.3, 8.1). However, the Czech solutan indet. is here interpreted as a probable basal dendrocystitid, because of the absence of any "sugar-loaf" suranal plate in its wide circular periproct (see Lefebvre et al. 2012, figs 6.2, 6.4, 7.2, 8.2). The presence of "sugar-loaf" elements is considered here as an apomorphy of the family Dendrocystitidae (see below). The stratigraphic range of dendrocystitid solutans extends at least from the Middle Ordovician (solutan indet. from the Prague Basin) to the Early Devonian (Claritacarpus, Dehmicystis, Rutroclypeus). However, a yet undescribed solutan from the late Cambrian (Furongian) of China (Zamora et al. 2012) may represent the oldest known dendrocystititid.

\section{Family Dendrocystitidae Bassler, 1938}

Diagnosis. - A family of dendrocystitids with a large circular periproct containing one or two suranals ("sugar-loaf" plates). Brachiole inserted either in apical position, or more posteriorly, along the anal thecal margin.

Discussion . - Individual solutan genera were initially assigned to various families of "cystoids", such as echinosphaeritids 
(Neumayr 1889), anomalocystitids (Miller \& Gurley 1894, Zittel 1903, Thomas \& Ladd 1926, Strimple 1953), and aristocystitids (Haeckel 1896). The family Dendrocystidae (name later corrected into Dendrocystitidae Bassler, 1938) was originally defined by Bather $(1899,1900)$, so as to include all "cystoid" genera with a single brachiole inserted into the theca (Dendrocystites, Syringocrinus). Consequently, in its original conception, the family Dendrocystitidae matches closely the modern definition of the class Soluta. However, as originally defined by Jaekel (1901), the suborder Soluta was comprising the two families Dendrocystitidae and Rhipidocystidae. As later demonstrated by Hecker (1940), the putative affinities between dendrocystitids and rhipidocystids suggested by Jaekel $(1901,1918)$ were largely based on a chimeric fossil, resulting from the fortuitous association of a solutan homoiostele with thecal fragments belonging to an ophiocistioid (Volchovia) and two eocrinoids (Bockia and Rhipidocystis; see also Ubaghs 1967a, Rozhnov \& Jefferies 1996). Consequently, the family Rhipidocystidae was removed from the order Soluta by Hecker (1940), and placed within the class Eocrinoidea by Ubaghs (1960). As a consequence, the order Soluta was then comprising the single family Dendrocystitidae. However, in the 1960s, most dendrocystitid genera were progressively assigned to new solutan families (e.g., Iowacystidae Gill \& Caster, 1960; Syringocrinidae Parsley \& Caster, 1965; Minervaecystidae Ubaghs \& Caster in Caster, 1967). As redefined here, the family Dendrocystitidae comprises the genera Claritacarpus, Dehmicystis, Dendrocystites, Dendrocystoides, Girvanicystis, Maennilia, Rutroclypeus, and probably Heckericystis (see discussion below).

\section{Genus Dendrocystites Barrande, 1887}

Type species. - Cystidea sedgwicki Barrande, 1867, from the Berounian (Upper Ordovician) of the Prague Basin. By original designation.

Emended diagnosis. - A genus of dendrocystitid solutan with a cordiform to pear-shaped theca, with a prominent preanal lobe and no antibrachial lobe. Thecal surfaces without any strong ridge or crest, and both made of numerous, unorganized platelets. Brachiole inserted in apical position. Periproct with a single suranal ("sugar-loaf") plate.

Discussion. - Most solutan species were initially assigned to the genus Dendrocystites: for example, the type species of Dendrocystoides Jaekel, 1918, Dehmicystis Caster, 1967 and Minervaecystis Ubaghs, 1970 were originally described as Dendrocystites scoticus, D. globulus and D. vidali, respectively (Bather 1913, Dehm 1934, Thoral 1935). Moreover, several taxa originally placed within other solutan genera were frequently secondarily also assigned to
Dendrocystites: for example, Syringocrinus paradoxicus Billings, 1859 and Iowacystis sagittaria Thomas \& Ladd, 1926 were both subsequently assigned to the genus Dendrocystites by Bather (1913, 1928; see also Bassler 1915, 1938; Dehm 1934; Chauvel 1941; Bassler \& Moodey 1943; Regnéll 1945). Finally, various solutan fragments were also originally attributed to Dendrocystites: for example, D. rossicus Jaekel, 1901 and D. sp. (see Regnéll 1945). In the last 50 years, most solutan taxa were removed from Dendrocystites and assigned to other genera. Consequently, in most recent contributions, only three species are still generally assigned to the genus Dendrocystites: D. sedgwicki (Barrande, 1867), D. rossicus Jaekel, 1901, and D. barrandei Bather, 1913 (Caster 1967, Rozhnov \& Jefferies 1996, Lefebvre et al. 2005). Dendrocystites rossicus, from the Kunda regional stage of St Petersburg area (Darriwilian), is known only from fragmentary portions of the dististele (see Jaekel 1901, 1918; Bather 1913; Hecker 1940; Rozhnov \& Jefferies 1996). Although imperfectly known, the morphology of the dististele of $D$. rossicus is strongly flattened, keeled, and not dendrocystitid-like (see Bather 1913, Parsley \& Caster 1965, Ubaghs 1970). If this observation is correct, then $D$. rossicus more likely belongs to an unknown genus of syringocrinid solutan. The morphology of the solutan Heckericystis kuckersiana from the Kukruse regional stage of St Petersburg area (Sandbian) is also imperfectly known (Hecker 1940, Gill \& Caster 1960, Caster 1967, Rozhnov \& Jefferies 1996). However, its thecal mophology and the presence of a single sugar-loaf suranal plate both suggest that $H$. kuckersiana may possibly represent a third species of Dendrocystites.

Stratigraphic range. - Upper Ordovician (Sandbian to early Katian).

\section{Dendrocystites barrandei Bather, 1913}

Figures 1, 5A-F, 9A-D

1887 Dendrocystites sedgwicki (Barrande). - Barrande, p. 142, pl. 27, figs 1, 5, 17-23.

1913 Dendrocystis barrandei sp. nov.; Bather, p. 383, text-figs 6, 7, pl. 1, figs 1-4.

1926 Dendrocystis barrandei Bather. - Bather, text-fig. 6.

1928 Dendrocystis barrandei Bather. - Bather, p. 5.

1934 Dendrocystites (Dendrocystites) barrandei Bather. Dehm, p. 21.

1935 Dendrocystites barrandei Bather. - Thoral, p. 109.

1941 Dendrocystis barrandei Bather. - Chauvel, p. 241.

1943 Dendrocystites barrandei Bather. - Bassler \& Moodey, p. 34.

1945 Dendrocystites barrandei Bather. - Regnéll, p. 195.

1966 Dendrocystites sedgwicki (Barrande). - Havlíček \& Vaněk, p. 54. 
1967 Dendrocystites barrandei Bather. - Caster, p. 608, text-figs 384.2, 385.

1970 Dendrocystites barrandei Bather. - Ubaghs, p. 102.

1965 Dendrocystites barrandei Bather. - Parsley \& Caster, p. 157 , text-fig. 11.

1982 Dendrocystites sedgwicki (Barrande). - Havlíček, p. 117.

1996 Dendrocystites n. sp. - Gil Cid et al., text-fig. 4.2.

1998 Dendrocystites sedgwicki (Barrande). - Chlupáč et al., p. 70.

1999 Dendrocystites barrandei Bather. - Prokop \& Petr, p. 63 , table 1.

2002 Dendrocystites sp. - Ausich et al., p. 977.

2002 Dendrocystites barrandei Bather. - Domínguez et al., p. 48.

2002 Dendrocystites sp. - Arroyo \& Lara, p. 103.

2009 Dendrocystites barrandei Bather. - Rak, p. 14.

2009 Dendrocystites sedgwicki (Barrande). - Nardin et al., text-fig. 3.

Material. - The examined material of Dendrocystites barrandei from the Prague Basin comprises about 150 specimens registered in Prague, Czech Republic (Czech Geological Survey and National Museum), 5 specimens from Berlin, Germany (Museum für Naturkunde: MB Ca 23-25, MB E 6219, MB E 6311), 9 specimens from London, UK (Natural History Museum: BMNH E16022-6030), 24 specimens from Vienna, Austria (Naturhistorisches Museum: NMW 1890/0002/0012, NMW 1894/0008/0020.1-3, NMW 1894/0010/0035, NMW 1903/0006/0185.1-5, NMW 1903/0006/0186, NMW 1903/0008/0002.1-4, NMW 1903/0008/0003.1-4, NMW 1982/0079/0082, NMW 2006z0349/0004, NMW 2006z0350/0004.1-3), 7 specimens from Stockholm, Sweden (Naturhistorica Riksmuseet: EC 5538, RC 19929, EC 19930, EC 30524-30527), and 3 specimens from Villeurbanne, France (Université Lyon 1: FSL 711164-711166).

Discussion. - Barrande's original description of Dendrocystites sedgwicki was based primarily on abundant material from the locality of Zahořany (Zahořany Formation, Katian), complemented with fewer specimens from Trubská (Letná Formation, Sandbian) and Trubín (Vinice Formation, Sandbian; Barrande 1867, 1887). The stratigraphically older solutans from the Letná Formation were assigned to a distinct species ( $D$. barrandei) by Bather (1913). The main morphological differences between the two species of Czech Dendrocystites were thoroughly investigated by Bather (1913) and Caster (1967). They concern: (1) thecal size: the largest individuals of $D$. barrande $i$ are about one third smaller than those of D. sedgwicki; (2) thecal outlines: they are less lobate and more symmetrical in D. barrandei than in D. sedgwicki; (3) thecal ornamentation: thecal plates are smooth in all specimens of
D. barrandei, whereas some of them display a typical ornamentation (delicate radiating ridges extending from a central knob) in large individuals of D. sedgwicki; (4) thecal plating: the theca of $D$. barrande $i$ is made of fewer, comparatively larger skeletal elements than in $D$. sedgwicki; and (5) plating of the proxistele: the proxistele of D. barrandei is invariably organized into distinct tetramerous rings, separated by few integumentary platelets, whereas platelets are much more abundant in between successive rings in the proxistele of large specimens of $D$. sedgwicki.

Reexamination of about 300 specimens of Czech Dendrocystites entirely confirms that all specimens from the Letná Formation are small to medium-size solutans, with a well-organized proxistele and a pear-shaped symmetrical theca consisting of few, relatively large and unornamented skeletal elements (Fig. 5). It also confirms that the largest specimens of Dendrocystites from the Zahořany Formation have a more unorganized proxistele and a more asymmetrical theca made of numerous, comparatively smaller plates, some of them displaying a strong ornamentation. However, the reexamination of the Czech material led to two more unexpected observations: (1) the morphology of small to medium-size specimens of Dendrocystites from the Zahořany Formation was remarkably similar to that of D. barrandei (see e.g., Caster 1967, fig. 382.5; Fig. 6A, B); and (2) several specimens from the Zahořany Formation were intermediate (Fig. 6C, D, G, I) both in size and in morphology between small to medium-size $D$. barrandei-like specimens and the largest, D. sedgwicki-like ones (Fig. 6E, F, H, J-K).

In specimens from the Zahořany Formation, a regular increase in the strength of thecal ornamentation can be documented from entirely smooth skeletal elements (small to medium-size individuals; Fig. 7A), to the presence, on some thecal plates, of a small central knob (large individuals; Fig. 7B) and finally, of a strong cone with radiating ridges (largest individuals; Fig. 7C). The same ontogenetic pattern of regular strengthening of thecal ornamentation was described in Maennilia estonica (see Parsley et al. 2012, p. 467).

The observation of numerous specimens of Dendrocystites from the Zahorany Formation also shows that the theca of small to medium-size specimens is made of a limited number of relatively large skeletal elements (D. barrandei condition). In larger individuals, numerous polygonal platelets are added in between and around preexisting larger thecal plates, thus producing the typical "rosetting pattern" described by Caster (1967, p. 608; see also Bather 1913, p. 388). However, such a rosetting pattern is not unique to Dendrocystites sedgwicki, but occurs also in other solutans (e.g., Rutroclypeus; Gill \& Caster 1960), and indeed in most blastozoans with a polyplated, unorganized theca (e.g., Balantiocystis, Eumorphocystis; see Sprinkle \& Guensburg 2001, fig. 2). A similar pattern 
of thecal growth by insertion of successive generations of plates was also described in some basal edrioasteroids and primitive crinoids (Sprinkle \& Guensburg 2001, Guensburg \& Sprinkle 2003). Consequently, the distinctive plate pattern observed in the largest individuals of $D$. sedgwicki simply results from their larger thecal size, and the insertion of numerous secondary platelets between large primary elements.

Similarly, the examination of the abundant material of Dendrocystites sedgwicki from the Zahořany Formation confirms the growth pattern already described by Caster (1967, p. 597) for the proxistele (Fig. 8). All possible morphological intermediates can be observed, from well-organized proxisteles, with distinct tetramerous rings and few intercalated platelets (small to medium size specimens; $D$. barrandei condition) to almost completely unorganized ones, with disrupted rings entirely submerged within numerous platelets (largest specimens of $D$. sedgwicki).

Consequently, small to medium size individuals of D. barrandei and D. segdwicki are morphologically identical. Distinctive characters of $D$. sedgwicki occur only in the largest specimens, and are apparently all size-related (e.g., stronger ornamentation, rosetting pattern of thecal plates, proliferation of platelets in the proxistele). It seems unlikely that the absence of large $D$. sedgwicki-like individuals in the Letná Formation results from a taphonomic bias (selective preservation of small to medium size $D$. barrandei-like specimens). A wide range of thecal sizes is observed for individuals of Dendrocystites in both the Letná and the Zahořany Formation. In both stratigraphic levels, palaeoenvironmental and taphonomic conditions were relatively similar, and no evidence of size sorting was reported so far (Chlupáč 1993, Mikuláš 1999, Kácha \& Šarič 2009, Fatka et al. 2013). Moreover, the skeleton of Dendrocystites is composed of hundreds of loosely articulated skeletal elements: this condition is typical of "type 1 " taxa in the qualitative taphonomic classification of echinoderms proposed by Brett et al. (1997; see also Lefebvre 2007). Taphonomic attributes of the Dendrocystites horizons from the Letná and Zahořany formations compare closely with those described in other Early Palaeozoic echinoderm Lagerstätten (see e.g., Ubaghs \& Robison 1985, Brett et al. 1997, Lefebvre 2007, Zamora et al. 2013). The preservation of hundreds of complete, fully articulated individuals in shallow, high-energy, siliciclastic storm-generated deposits probably results from the rapid and deep burial of life and/or immediate post-mortem com- munities by a sudden influx of sediments. Organisms were preserved either in situ or displaced along a short distance. The alignment of specimens suggests that entombment was probably caused by a single, unidirectional obrution event. Consequently, the two exceptionally preserved dense assemblages of Dendrocystites from the Prague Basin provide very likely a relatively accurate picture of the original populations. This implies that the absence of D. sedgwicki-like large specimens in the Letná Formation is probably original.

The co-occurrence of $D$. barrandei-like and $D$. sedgwicki-like solutans in the same levels of the Zahořany Formation questions both the stratigraphic range of $D$. barrandei and the existence of a putative (sexual?) dimorphism in Dendrocystites. However, the possibility that small to medium size specimens from the Zahořany Formation belong to $D$. barrandei and all larger co-occurring individuals to a distinct species (D. sedgwicki) can be ruled out because the same stratigraphic levels have yielded specimens displaying all intermediate morphologies between these two morphotypes. For the same reason, the existence of a putative dimorphism can be also excluded (moreover, large $D$. sedgwicki-like specimens are absent in the Letná Formation). The co-occurrence of small to medium size $D$. barrandei-like and large $D$. sedgwicki-like solutans in the Zahořany Formation is here interpreted as the result of heterochronic processes (peramorphosis) (Fig. 9). It is suggested that the ontogenetic development of solutans from the Zahořany Formation was extending beyond that of the stratigraphically older ones from the Letná Formation, thus permitting the addition of new stages (and associated morphological innovations) to the end of the ancestral developmental sequence. If this interpretation is correct, then all morphological features unique to the largest specimens of $D$. sedgwicki would then correspond to hyperadult characters (e.g., acquisition of more asymmetrical thecal outlines, strengthening of thecal ornamentation, insertion of secondary platelets between and around larger primary thecal plates, proliferation of unorganized skeletal elements within the proxistele). Consequently, it is suggested here that the two successive species of Late Ordovician dendrocystitids from the Prague Basin constitute a peramorphocline, with the largest individuals of $D$. sedgwicki displaying hyperadult morphologies (hypermorphosis). This interpretation is in good agreement with observations made in other blastozoans possessing a polyplated theca: opposite patterns showing a

Figure 5. Dendrocystites barrandei Bather, 1913. • A - NMP.L.13145, upper surface, Letná Formation; specimen originally figured by Barrande (1887, pl. 27, fig. 20, 21)••B - MB.E.6219, upper surface, Letná Formation; specimens originally figured by Caster (1967, fig. 385). C - NMP.L.10676, upper surface, Letná Formation; specimen originally figured by Barrande (1887, pl. 27, figs 22, 23). • D - CGSP.JH.1106, upper surface, Letná Formation. • E - NMW.1894/0010/0035, lower surface, Letná Formation. • F - NMP.L.31144, upper surface, Vinice Formation; specimen originally figured by Barrande (1887, pl. 27, fig. 18). All photographs from latex casts. 

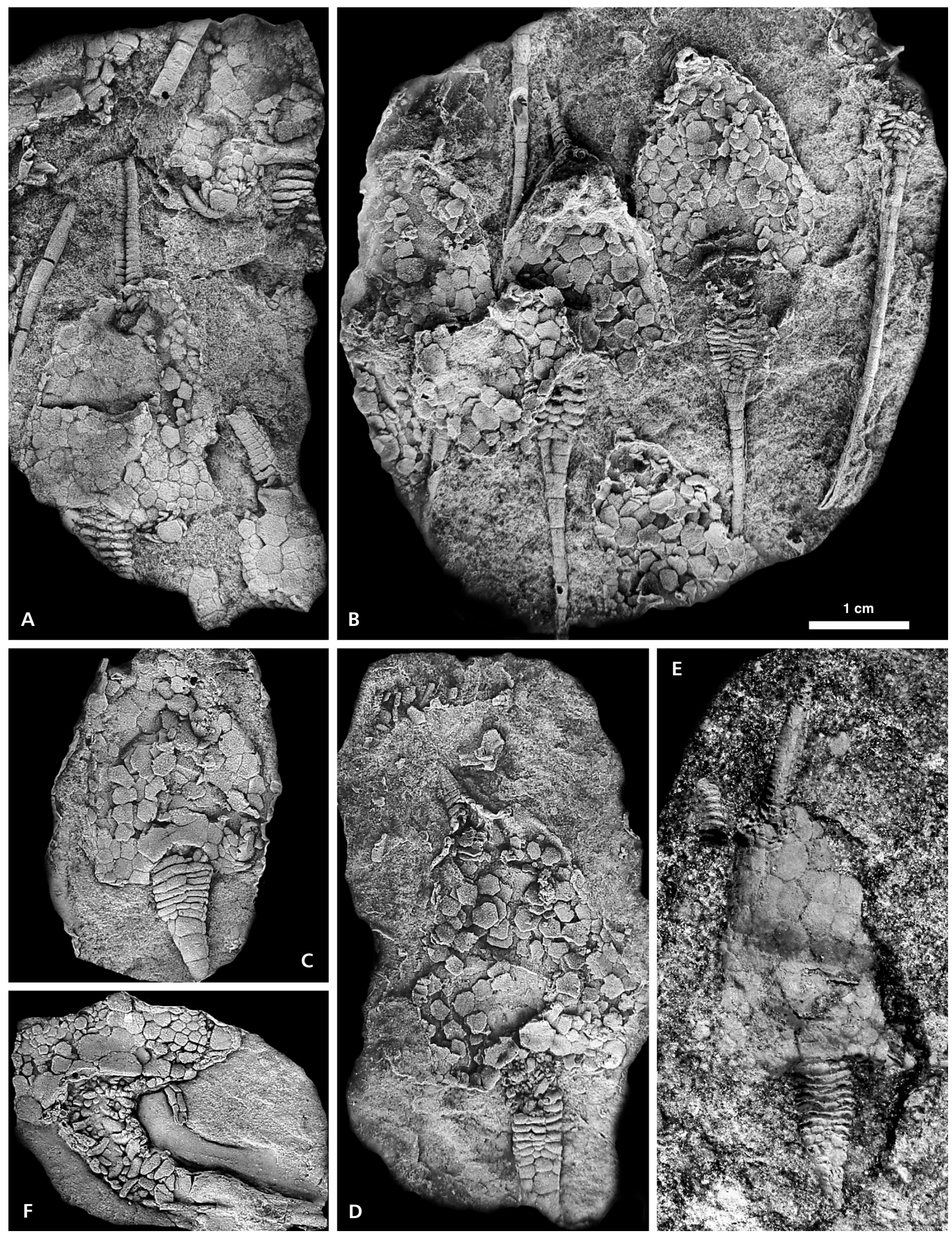
drastic reduction in the number of thecal plates are generally considered as paedomorphic (see e.g., Sprinkle \& Guensburg 2001).

The Vinice Formation has yielded very few specimens of Dendrocystites (see above). All specimens known so far (including the specimen figured in Barrande 1887, pl. 27, fig. 18; see Bather 1913, p. 388) correspond to small to medium size individuals. The number of available specimens is currently too reduced to determine if they should be definitely assigned to $D$. barrandei or to $D$. sedgwicki. In the absence of large individuals showing hyperadult characters typical of D. sedgwicki, all specimens of Dendrocystites from the Vinice Formation are here provisorily assigned to D. barrandei. Similarly, all specimens of Dendrocystites observed so far from the Sandbian of Spain (Pizarras Cantera Formation) correspond to small to medium size $D$. barrandei-like individuals. This material is thus provisorily identified as $D$. barrandei too, pending a more intensive sampling.

Occurrence. - Letná and Vinice formations, Prague Basin, Czech Republic (Barrande 1887, Bather 1913, Caster 1967; L. Kašička, pers. obs.); Pizarras Cantera Formation, El Viso del Marqués, Ciudad Real Province, Spain (Gil Cid et al. 1996, Arroyo \& Lara 2002, Ausich et al. 2002).

\section{Dendrocystites sedgwicki (Barrande, 1867)}

Figures 6A-K, 7A-C, 8A-C, 9E, F, 10

1867 Cystidea sedgwicki sp. nov.; Barrande, p. 179.

1887 Dendrocystites sedgwicki (Barrande). - Barrande, p. 142 , pl. 26, figs $1-22$, pl. 27, figs 2-4, 6-16.

1889 Dendrocystites sedgwicki (Barrande). - Neumayr, text-fig. 107.

1896 Dendrocystis sedgwicki (Barrande). - Haeckel, p. 55.

1900 Dendrocystis sedgwicki (Barrande). - Bather, text-fig. 9.

1901 Dendrocystites sedgwicki (Barrande). - Jaekel, p. 673 , text-fig. 9 .

1913 Dendrocystis sedgwicki (Barrande). - Bather, p. 387, text-fig. 8, pl. 1, figs 5-9.

1915 Dendrocystites sedgwicki (Barrande). - Bassler, p. 398.

1926 Dendrocystis sedgwicki (Barrande). - Bather, text-fig. 7.

1928 Dendrocystis sedgwicki (Barrande). - Bather, p. 6.

1934 Dendrocystites (Dendrocystites) sedgwicki (Barrande). - Dehm, p. 21, text-fig. 6b.

1935 Dendrocystites sedgwicki (Barrande). - Thoral, p. 109.

1941 Dendrocystis sedgwicki (Barrande). - Chauvel, p. 234.

1943 Dendrocystites sedgwicki (Barrande). - Bassler \& Moodey, p. 34.

1945 Dendrocystites sedgwicki (Barrande). - Regnéll, p. 195.
1960 Dendrocystites sedgwicki (Barrande). - Easton, p. 597, text-fig. 14.8 .

1960 Dendrocystites sedgwicki (Barrande). - Gill \& Caster, p. 25 , text-fig. 2.

1965 Dendrocystites sedgwicki (Barrande). - Parsley \& Caster, p. 129, text-fig. 11.

1966 Dendrocystites batheri nomen nudum. - Havlíček \& Vaněk, p. 57.

1967 Dendrocystites sedgwicki (Barrande). - Caster, p. 608 , text-figs $372,377,378.1,382.1-5,383.1-3$.

1978 Dendrocystites aff. sedgwicki (Barrande). - Gupta \& Termier, p. 476, text-fig. 3, pl. 1, figs 3, 4.

1982 Dendrocystites sedgwicki (Barrande). - Jell \& Holloway, p. 42.

1989a Dendrocystites sedgwicki (Barrande). - Petr, p. 6, text-figs 2, 6, 7, pl. 1, pl. 4, fig. 2, pl. 7, 8 .

1990 Dendrocystites sedgwicki (Barrande). - Jefferies, p. 639.

1993 Dendrocystites sedgwicki (Barrande). - Benton, p. 532.

1993 Dendrocystites batheri nomen nudum. - Chlupáč, p. 56.

1995 Dendrocystites sedgwicki (Barrande). - Mikuláš et al., p. 20.

1996 Dendrocystites sedgwicki (Barrande). - Rozhnov \& Jefferies, p. 94, text-fig. 6.

1998 Dendrocystites sedgwicki (Barrande). - Parsley, p. 255.

1999 Dendrocystites sedgwicki (Barrande). - Allasinaz, p. 712, text-figs $19.5 .1 \mathrm{a}, \mathrm{b}$.

1999 Dendrocystites sedgwicki (Barrande). - Prokop \& Petr, p. 66, table 1.

2002 Dendrocystites sedgwicki (Barrande). - Domínguez et al., p. 48.

2009 Dendrocystites sedgwicki (Barrande). - Kácha \& Šarič, p. 171.

2010 Dendrocystites sp. - Hunter et al., text-figs 4, 5.

2010 Dendrocystites sedgwicki (Barrande). - Lefebvre et al., text-fig. 7A.

2012 Dendrocystites sedgwicki (Barrande). - Lefebvre et al., p. 288.

Material. - The studied material of Dendrocystites sedgwicki from the Prague Basin comprises about 100 specimens registered in Prague, Czech Republic (Czech Geological Survey and National Museum), 1 specimen from Berlin, Germany (Museum für Naturkunde: MB E 6490), 5 specimens from London, UK (Natural History Museum: BMNH E16018- 16021, BMNH E16031), and 2 specimens from Vienna, Austria (Naturhistorisches Museum: NMW NMW 1900/0002/0004.1-2).

Discussion. - Dendrocystites sedgwicki is particularly abundant in the Zahořany Formation of the Prague Basin. 


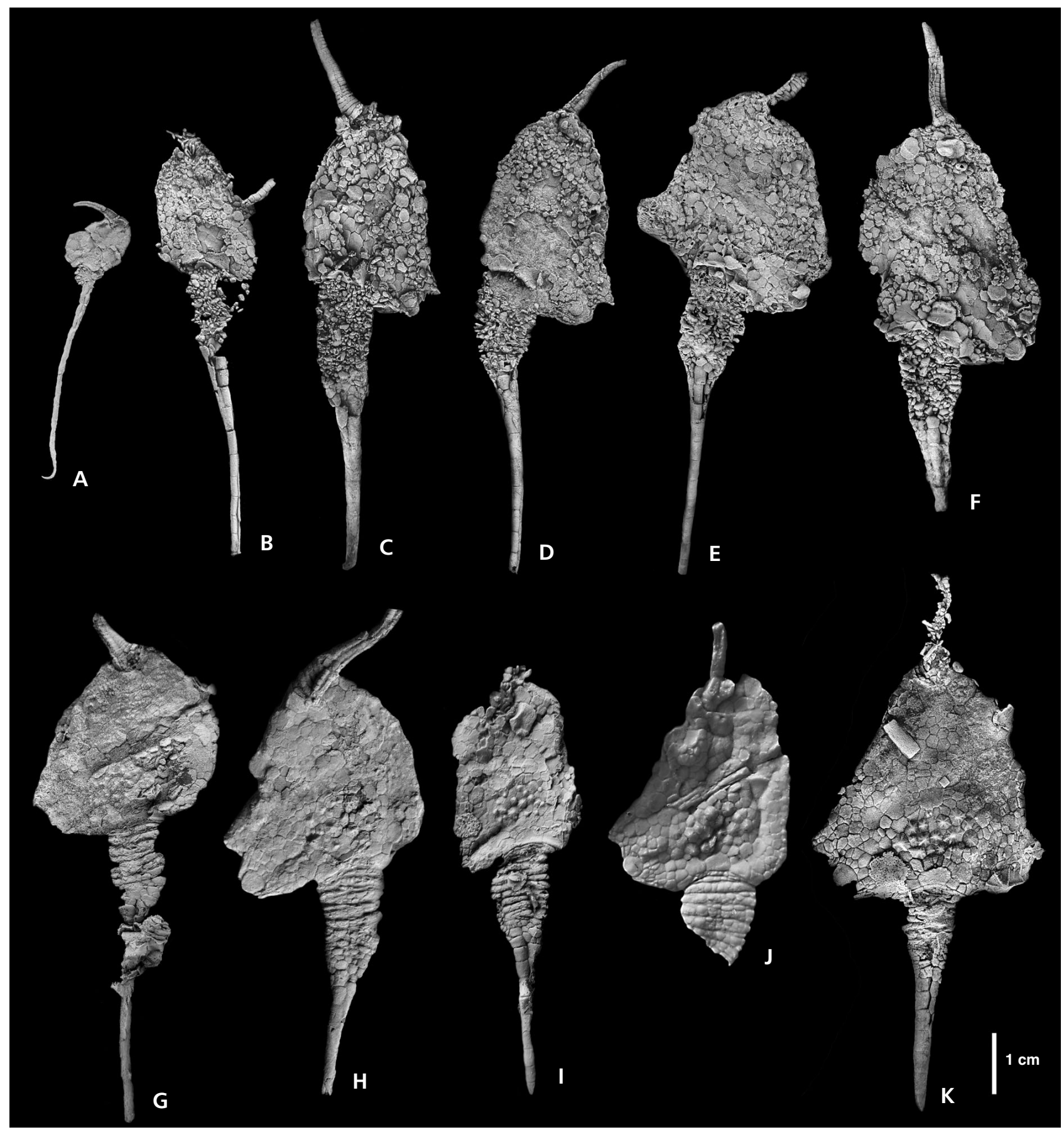

Figure 6. Dendrocystites sedgwicki (Barrande, 1867). All specimens from the Zahořany Formation. - A - NMP.13/1989, lower surface. - B - NMP.L.13142, upper surface; specimen originally figured by Barrande (1887, pl. 27, figs 8, 9). $\bullet$ - NMP.L.13138, upper surface; specimen originally figured by Barrande (1887, pl. 26, figs 14, 15). $\bullet$ D - NRS.Ec.30524, upper surface. $\bullet$ E - NRS.Ec.30523a, upper surface. $\bullet$ F - NMP.L.10662, upper surface; specimen originally figured by Barrande (1887, pl. 26, figs 16, 17). $\bullet$ - NMP.L.10667, lower surface; specimen originally figured by Barrande (1887, pl. 26, figs 20, 21) • H - NMP.L.40531, lower surface; specimen originally figured by Caster (1967, fig. 383.3). • I- NMP.L.10673, lower surface; specimen originally figured by Barrande (1887, pl. 27, figs 12, 13). - J - NMP.L.10663, lower surface; specimen originally figured by Caster (1967, fig. 383.2). K - NMP.L.13136, lower surface; specimen designated as lectotype of $D$. sedgwicki by Bather (1913, p. 388), originally figured by Barrande (1887, pl. 26, figs 6, 7) and Caster (1967, fig. 383.1). Photographs from latex (A-I, K-L) and polyurethane (J) casts.

Its occurrence in the overlying Bohdalec Formation is reported here for the first time, based on the recent discovery of a single large specimen displaying the typical hyperadult morphology of D. sedgwicki (L. Kašička, pers. obs). Abundant remains of Dendrocystites were recently reported from the top of the Lower Ktaoua Formation (early Katian) 

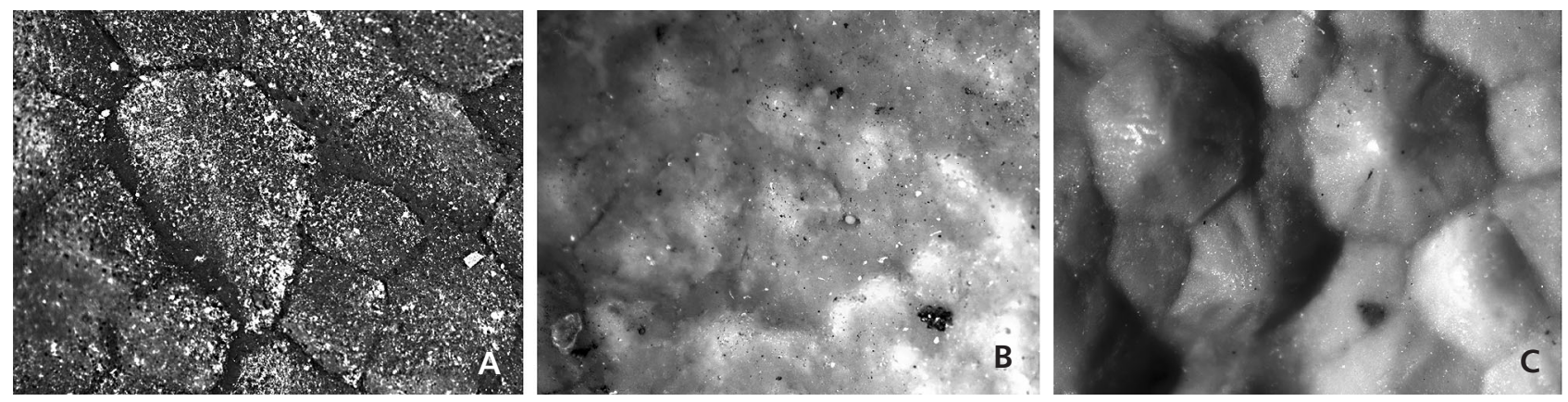

Figure 7. Dendrocystites sedgwicki (Barrande, 1867), Zahořany Formation. Growth pattern of ornamentation on lower thecal surface. All photographs $\times 16$. A - NMP.L.1/56/13 (latex cast): smooth plates. $\bullet$ B - NMP.L.10664 (polyurethane cast): plates with small central knob. $\bullet$ C - NMP.L.10663 (polyurethane cast): plates with strong central cone and radiating ridges.
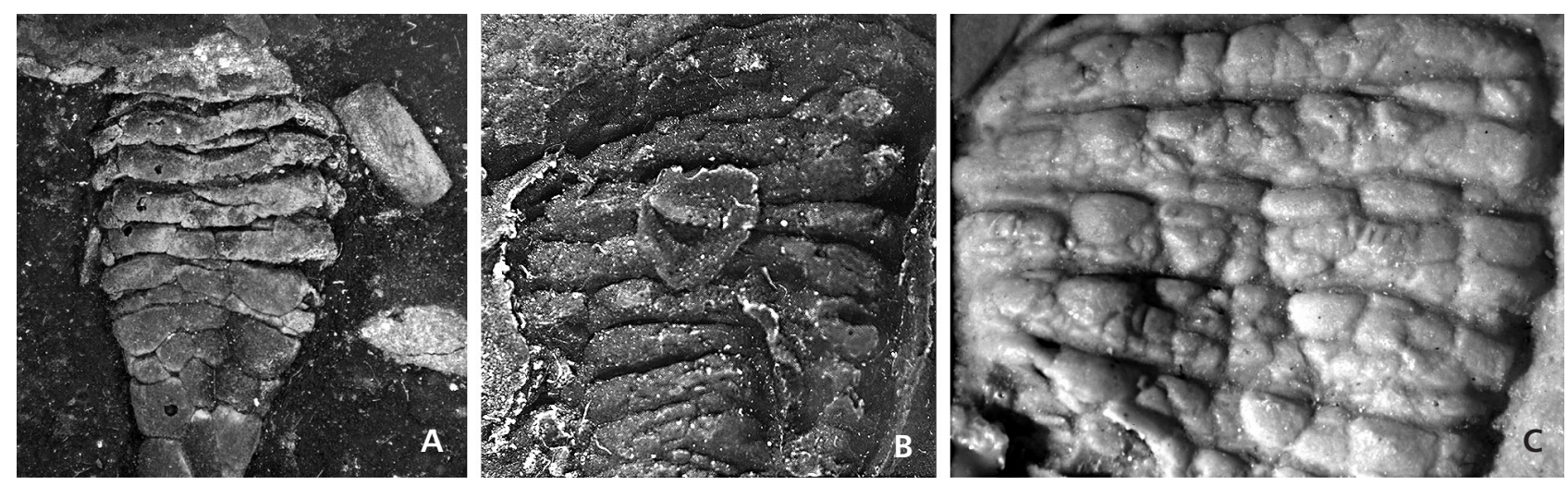

Figure 8. Dendrocystites sedgwicki (Barrande, 1867), Zahořany Formation. Growth pattern of the proxistele; all specimens $\times 8$. $・$ A - NMP.L.1/56/13 (latex cast): well-organized tetramerous rings (latex cast). B - NMP.L.10673 (latex cast): partially disorganised proxistele. $\bullet$ C - NMP.L.10663 (polyurethane cast): totally disorganised proxistele.

in the eastern Anti-Atlas, Morocco (Lefebvre et al. 2007, 2010; Hunter et al. 2010). Pending the detailed description of the Morocan material of Dendrocystites, it is provisorily assigned here to D. sedgwicki, because of the co-occurrence, in the same stratigraphic levels, of small to medium size $D$. barrande $i$-like individuals with larger, D. sedgwicki-like ones. A specimen of Dendrocystites aff. sedgwicki was described by Gupta \& Termier (1978) from the Middle? Ordovician of Nepal. However, as pointed out by Webster (1991), this record appears as extremely doubtful: all Ordovician taxa mentioned in that paper are known from the Prague Basin (i.e., the diploporan Codiacystis bohemica, the mitrate Lagynocystis pyramidalis, and the solutan Dendrocystites aff. sedgwicki). Moreover, their preservation is very Bohemian-like, and very different from that of fossils actually collected in the Kathmandu area (see Talent 1990). It is thus very likely that the single specimen of Dendrocystites figured by Gupta \& Termier (1978) was probably not collected in the Himalaya, but more likely in the Prague Basin.

Occurrence. - Zahořany and Bohdalec formations, Prague Basin, Czech Republic (Barrande 1887, Bather 1913, Cas- ter 1967; L. Kašička, pers. obs.); uppermost part of the Lower Ktaoua Formation, Jbel Tijarfaïouine, eastern Anti-Atlas, Morocco (Lefebvre et al. 2007, 2010; Hunter et al. 2010).

\section{Palaeoecology of Dendrocystites}

In the Upper Ordovician of Bohemia, Dendrocystites occurs massively in some horizons of the Letná and Zahořany formations, but it is extremely rare in the Vinice and Bohdalec formations. Such a distribution pattern is not random, but coincides closely with first order fluctuations of the sea-level in the Prague Basin: the storm-influenced siltstones of the Letná and Zahořany formations correspond to relatively shallow environmental conditions, whereas the shale-dominated deposits of the Vinice and Bohdalec formations are generally interpreted as transgressive units, associated with a deepening of the Basin (Havlíček 1982, Havlíček \& Fatka 1992, Chlupáč et al. 1998, Mikuláš 1999). In both Morocco and Spain, dense assemblages of Dendrocystites are also apparently restricted to relatively coarse (siltstones, sandstones), storm-influenced deposits 
Figure 9. Ontogenetic sequences in Dendrocystites barrandei Caster, 1913, Letná Formation (A-D) and Dendrocystites sedgwicki (Barrande, 1867), Zahořany Formation (E, F). Morphologies associated to small and medium body sizes (A to D) are observed in both $D$. barrandei and D. sedgwicki. Morphologies associated with larger body sizes ( $\mathrm{E}$ to $\mathrm{F}$ ) are present only in D. sedgwicki. Camera-lucida drawings based on latex casts. - A - NMP.L.36117, upper surface. - B - NMP.13/1988, lower surface. • C - NMP.L.4833, upper surface. • D - NMP.L.6046, upper surface. • E - NMP.L.10673, lower surface. $\bullet$ F - NMP.L.10663, lower surface.

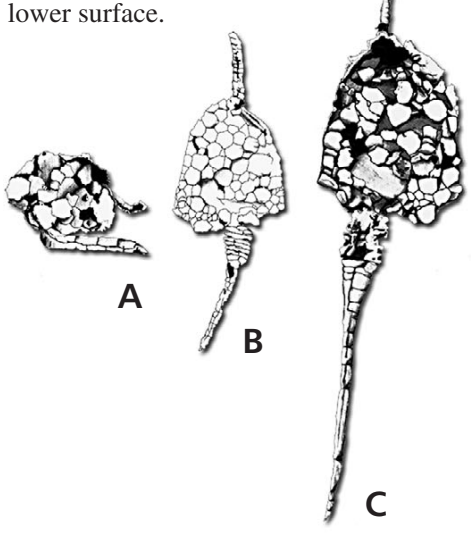

C

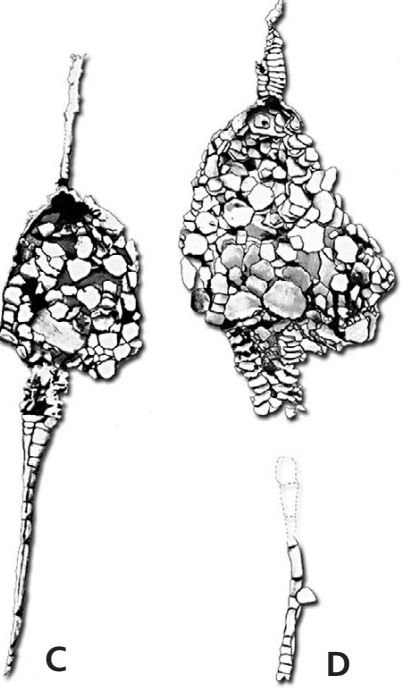

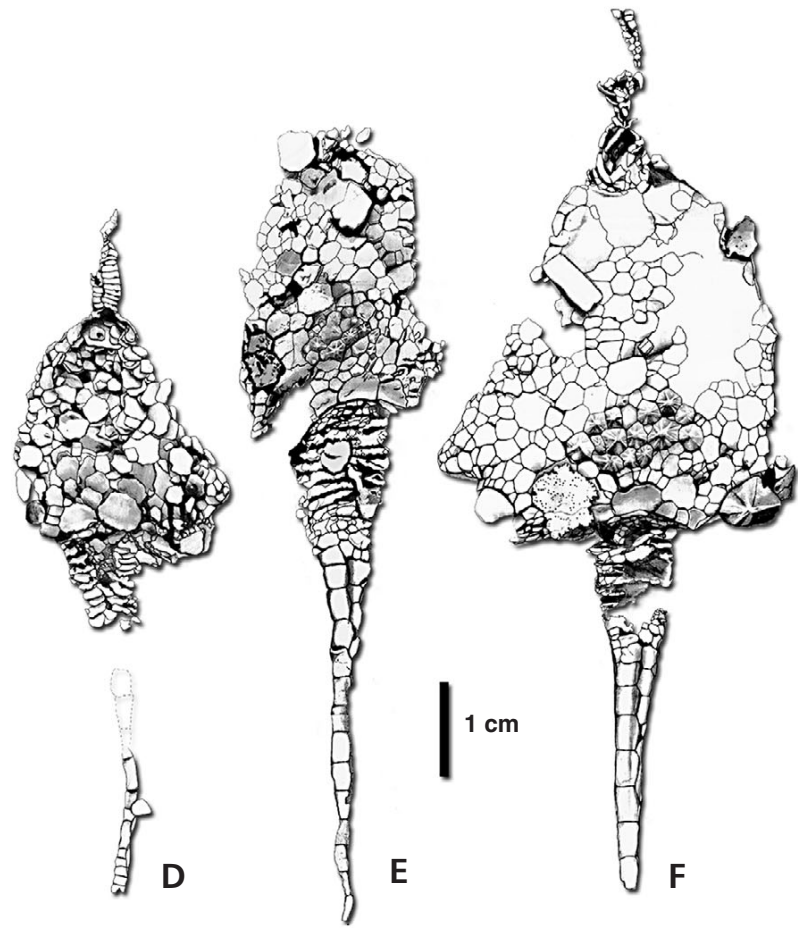

(Gil Cid et al. 1996; Lefebvre et al. 2007, 2010; Hunter et al. 2010). In all regions, dense assemblages of Dendrocystites are characterized by a low diversity associated fauna, generally dominated by other free-living, unattached echinoderms (e.g., glyptocystitid rhombiferans, ophiuroids, stylophorans). Other typical benthic organisms (e.g., bivalves, brachiopods, trilobites) are generally rare or absent in Dendrocystites-dominated horizons, whereas they occur more abundantly in both underlying and overlying parts of the succession (Petr 1989a, Lefebvre et al. 2010). However, the occurrence of a low diversity associated fauna is not unique to Dendrocystites-dominated assemblages, but apparently the rule in most Palaeozoic echinoderm dense beds (Ubaghs \& Robison 1988, Mikuláš et al. 1995, Hunter et al. 2007, Lefebvre 2007), as well as in dense populations of modern ophiuroids (Fujita 1992, Aronson \& Blake 1997). Both extant and fossil echinoderm dense beds are generally interpreted as opportunistic assemblages, associated with oligotrophic conditions and/or a low intensity of predation pressure (Fujita 1992, Aronson \& Blake 1997, Lefebvre 2007). In modern seas, asteroids, teleost fish and decapod crustaceans are the main predators feeding on benthic, free-living echinoderms (Fujita 1992, Aronson \& Blake 1997). In Late Ordovician times, both asteroids and cephalopods were already diverse and probably among the top predators feeding on benthic organisms (Blake \& Guensburg 1994, Lefebvre 2007, Kröger et al. 2009, Blake 2013). However, asteroid remains and cephalopod conchs are both rare or absent in Dendrocystites-dominated horizons, thus suggesting a low intensity of predation pressure.
In the Zahořany Formation, Petr (1989a) figured several exquisitely preserved specimens of the infaunal ophiuroid Bohemura jahni feeding on individuals of Dendrocystites sedgwicki (Fig. 10). However, it cannot be determined if ingested specimens of Dendrocystites were still alive or already dead, and thus if Bohemura was a predator or a scavenger.

The feeding behaviour of solutans is a long-standing controversial issue, which largely depends on the putative life orientation of the organism and more precisely, on the orientation of its single ambulacral ray, towards or away from the substrate. Following Bather (1913), solutans were often oriented with their ambulacral food groove facing away from the substrate, thus implying a suspension-feeding mode of life (e.g., Gill \& Caster 1960; Parsley \& Caster 1965; Caster 1967; Ubaghs 1970; Parsley 1972, 1982, 1997; Parsley et al. 2012; Rahman \& Lintz 2012). This orientation was based on three main arguments. The first one is that an upward-facing food groove is the rule in all echinoderms (Caster 1967, p. 587). Caster's statement certainly applies to various groups of both extinct and extant echinoderms (e.g., blastoids, crinoids, edrioasteroids, stylophorans), but the opposite orientation is also widespread in both extinct and extant taxa (e.g., asteroids, ophiuroids, pleurocystitid rhombiferans). The second argument concerns the hydropore: if solutans were living with their food-groove directed downwards, then their hydropore would not be functional, because it would be buried in the substrate (Parsley 1982, Parsley et al. 2012, Rahman \& Lintz 2012). This argument is not valid as well, 
because in several groups of both extant and extinct echinoderms (e.g., ophiocistioids, ophiuroids), the hydropore is located on the lower surface of the body, and is thus in permanent contact with the substrate (see e.g., Spencer \& Wright 1966, Ubaghs 1966). Similarly, the third argument concerns the location of the periproct: if solutans were oriented with their food-groove facing the substrate, then the anal opening would be directed towards the substrate in some taxa (e.g., Dehmicystis). Although such a location of the anal opening is considered as unlikely (Rahman \& Lintz 2012, p. 67), it is observed in other groups of free-living, epibenthic Palaeozoic echinoderms (e.g., kirkocystid mitrates, pleurocystitid rhombiferans; Sumrall 2000, Lefebvre 2003). Consequently, analogy with various groups of extant and extinct echinoderms indicates that the life orientation proposed by Bather (1913) for solutans is plausible (i.e., with the food groove directed away from the substrate). However, comparison with the situation in various other echinoderm taxa also suggests that the opposite life orientation cannot be ruled out on functional arguments.

Following Miller \& Gurley (1894), solutans were frequently interpreted as living with their ambulacral groove facing the substrate, thus implying a detritus-feeding mode of life (Kolata 1973; Sprinkle 1976; Kolata et al. 1977; Sprinkle \& Kier 1987; Jefferies 1990; Daley 1992, 1995, 1996; Gil Cid et al. 1996; Rozhnov \& Jefferies 1996; Guensburg \& Sprinkle 2001; Lefebvre et al. 2012). This presumed orientation was generally supported by three main arguments. The first one is based on a comparison with pleurocystitid rhombiferans (Kolata 1973, Kolata et al. 1977). Pleurocystitids were free-living, unattached detritus-feeding blastozoans characterized by a reduced number of brachioles and a flattened theca (Paul 1967, 1984; Parsley 1970; Sprinkle 1974; Brower 1999; Sumrall 2000). In pleurocystitids, the thecal surface in contact with the substrate is made of numerous, polygonal platelets and was thus probably relatively flexible in life, whereas the opposite thecal side is composed of fewer, larger and stouter, tightly sutured skeletal elements. The observation of a similar thecal pattern in some derived solutans (e.g., Girvanicystis, iowacystids) was thus presented as an argument supporting a comparable, flexible thecal side-down life orientation. However, the plate pattern observed in pleurocystitids is not the rule in all echinoderms. For example, the opposite pattern occurs in both cinctan and stylophoran echinoderms: in both groups, the lower thecal surface is generally more rigidly plated and made of fewer, larger skeletal elements than the opposite, upper thecal side (Ubaghs 1967b, 1981; Friedrich 1993; Lefebvre 2000, 2003; Smith \& Zamora 2009). Consequently, the occurrence of a pleurocystitid-like thecal plate pattern in somes solutans cannot be considered as an unequivocal argument for their putative life orientation. The second main argu- ment supporting a downward-facing food-groove in solutans is based on the identification of left-right asymmetries and putative homologies with both stylophorans and chordates ("calcichordate theory"; Jefferies 1990, Daley 1992, Rozhnov \& Jefferies 1996, Rozhnov 2002). However, all recent phylogenies based on molecular data suggest that echinoderms are more closely related to hemichordates than to chordates (Smith 2005, 2008), thus implying that putative homologies identified by the calcichordate model are more likely morphological convergences (David et al. 2000, Prokop \& Petr 2003). Moreover, several homologies between and within echinoderm classes implied by the calcichordate theory are probably not valid (Philip 1979, Ubaghs 1981, Lefebvre 2000): for example, this model implies that the aulacophore was not homologous and oriented in opposite directions in both cornutes and mitrates (Jefferies 1986, 1990). The third argument supporting a detritus-feeding mode of life for solutans relies on the small size and unbranched morphology of their single feeding appendage, both presented as incompatible with a putative filter-feeding function (Paul 1977, Daley 1995). However, upward-facing food-grooves occur in various taxa of extinct, filter-feeding echinoderms with a single, unbranched ambulacral ray (e.g., the highly derived pleurocystitid Hillocystis, the crinoid Monobrachiocrinus, stylophorans; Ubaghs 1963, 1970, 1981; Jell 1983; David et al. 2000; Lefebvre 2003; Sevastopulo 2008). Consequently, the comparison with pleurocystitids suggests that a detritus-feeding mode of life is plausible in solutans. However, the alternative interpretation of solutans as filter-feeding organisms cannot be ruled out on functional arguments.

Although both orientations are equally plausible, several independent lines of evidence tend to suggest that the ambulacral groove of solutans was more likely facing the substrate (pleurocystitid-like orientation). First, the presumed life orientation of unattached, bottom-dwelling extinct echinoderms can be generally easily deduced based on general morpho-functional principles summarized by Thayer (1975) for marine invertebrates: in all benthic, free-living echinoderms (e.g., asterozoans, cinctans, ctenocystoids, cyclocystoids, echinoids, edrioasteroids, ophiocistioids, stylophorans), the surface of the body in contact with the substrate is typically flat to slightly concave, whereas the opposite side, away from the substrate, is generally more convex. However, such general principles cannot be applied in the case of solutans with poorly differentiated, polyplated thecal surfaces (e.g., Castericystis, Dehmicystis, Dendrocystites, Dendrocystoides, Maennilia, Minervaecystis, Plasiacystis, Rutroclypeus). In such taxa, the two opposite thecal surfaces were probably relatively flexible in life, and they generally collapsed after the death of the organism. The original body shape is better preserved in the case of solutans with a more rigid theca 


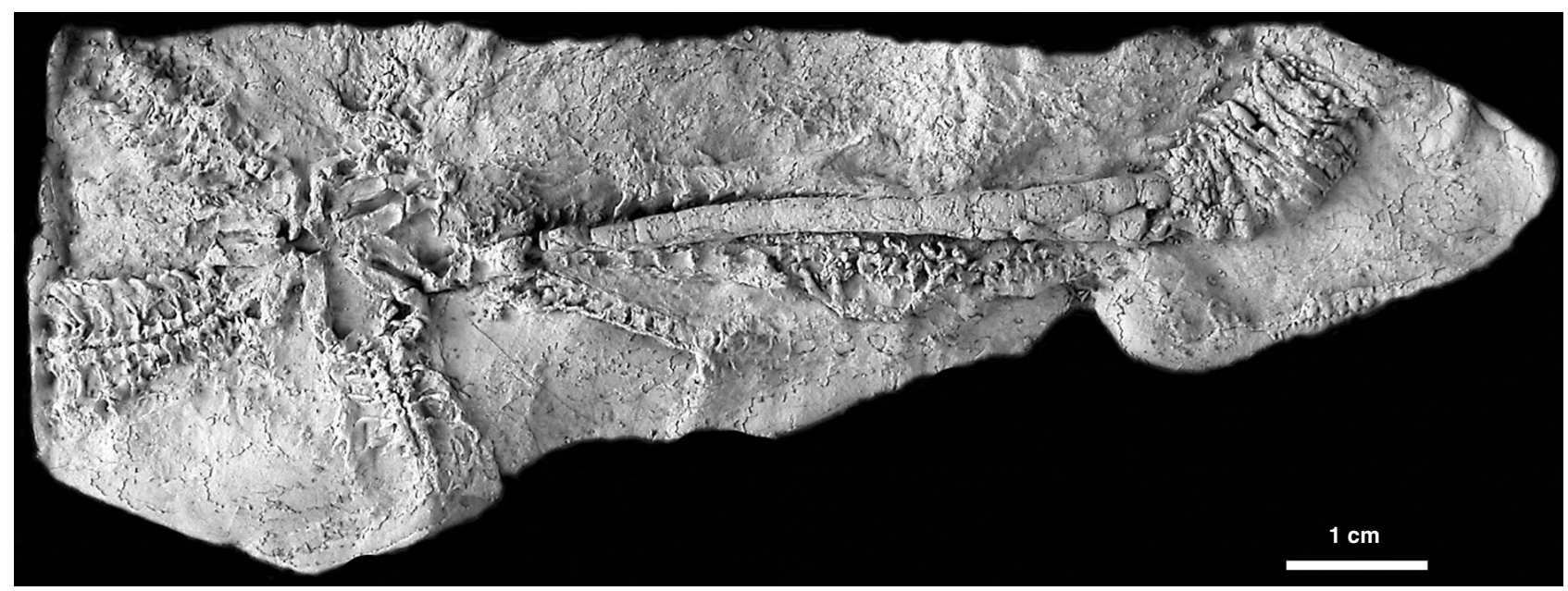

Figure 10. A specimen of the ophiuroid Bohemura jahni (Jaekel, 1903) ingesting homoiostele-first, an individual of Dendrocystites sedgwicki (Barrande, 1867); MB.E.6490a, latex cast, Zahořany Formation.

composed of fewer and/or more tightly sutured skeletal elements (e.g., Belemnocystites, Claritacarpus, Girvanicystis, Iowacystis, Scalenocystites). In these taxa, the thecal side made of fewer, larger, and stouter plates is invariably more convex than the opposite one (Kolata 1973, Kolata et al. 1977, Sprinkle \& Kier 1987, Daley 1992). By comparison with the situation in all other echinoderms, this suggests that the thecal side made of fewer and larger skeletal elements was very likely directed upwards in life in solutans. This orientation implies that the food-groove was located towards the substrate, and thus a detritus-feeding mode of life for solutans.

This interpretation is supported by two examples of epibiontic echinoderms attached to solutans. The first one was described in Castericystis vali, with both eocrinoids (Marjumicystis sp.) and numerous small (juvenile) individuals of $C$. vali preserved attached to various parts of the body, and in particular to the dististele of large specimens of C. vali (Ubaghs \& Robison 1985, Daley 1995). However, as pointed out by Daley (1995), the distribution of epibionts is not random in C. vali, but restricted to parts of the body, which were presumably not in contact with the substrate. In all observed specimens of $C$. vali, epibionts are consistently attached to the same side of the theca and/or of the dististele (see Daley 1995, pl. 76). The observed distribution of epibionts on $C$. vali suggests that the anal opening was located right of the homoiostele insertion, and that the food-groove was facing the substrate. A second example of epibiontic echinoderms fixed on solutans was recently reported in the Middle Ordovician of the Prague Basin, with a small isorophid edrioasteroid (?Agelacrinites bohemicus) attached to a specimen of the large solutan indet. described by Lefebvre et al. (2012). The thecal surface on which the edrioasteroid is fixed is more convex, and made of fewer, larger skeletal elements than the opposite one (Lefebvre et al. 2012). This thecal surface was presumably facing away from the substrate in life, so as to allow the settlement of the edrioasteroid larva. The resulting orientation (anal opening right of the homoiostele insertion, food groove directed downwards) is consistent with the distribution of epibionts in Castericystis, and the above-mentioned general morpho-functional principles defined by Thayer (1975). It is also in good accordance with the observed preferential orientation of most specimens of Scalenocysites strimplei preserved in situ, in calm, relatively deep deposits of the Dunleith Formation (Kolata 1973, p. 973).

Finally, a probable case of parasitic infestation was reported by Rozhnov \& Jefferies (1996, p. 101) in Maennilia estonica. This interpretation is based on the observation of two specimens showing several tiny holes opening through thecal plates. In both individuals, location of the perforations is not random, but restricted to plates belonging to the same side of the theca. Consequently, Rozhnov \& Jefferies (1996) concluded that the thecal surface showing evidence of parasitic drilling was probably facing upwards in life. However, Rozhnov \& Jefferies (1996) acknowledged that the implied life orientation of M. estonica (with the food groove facing away from the substrate) would then be opposite to that of all other solutans. Similar cases of parasitic infestation have been described in other Ordovician echinoderms: for example, Deline (2008) reported the occurrence of a single drillhole on the upper thecal surface of one specimen of the Late Ordovician mitrate Enoploura popei. However, in most cases, traces of bioerosion occur in internal moulds and on the lower, unexposed parts of the body (see e.g., Bruthansová \& Kraft 2003, Lefebvre 2007). Consequently, comparison with other occurrences of parasitic drillholes in Ordovician echinoderms suggests that the perforations observed in two specimens of $M$. estonica 
more likely occurred on the lower thecal surface. If this interpretation is correct, then the resulting life orientation of M. estonica (i.e., with the food groove facing downwards) would be consistent with both the morpho-functional principles of Thayer (1975), and the distribution of epibionts in other solutans (see above). At any rate, deductions of life habits of extinct organisms based on the location of parasitic drillholes on their body have to be considered extremely cautiously.

In summary, available evidence indicates that the ambulacral groove of solutans was facing the substrate, thus implying a detritus-feeding mode of life for these organisms.

\section{Acknowledgements}

This paper is a contribution of the team "Vie Primitive, biosignatures, milieux extręmes" of UMR CNRS 5276, and to the ANR project RALI (Rise of Animal LIfe). BL benefitted from the financial support made available by the European Community Research Infrastructure Action under the FP6 structuring the European Research Area Programme SYNTHESYS, to have access to material of Dendrocystites deposited in the collections of the Museum für Naturkunde, Berlin (SYNTHESYS project DE-TAF-4766), the Natural History Museum, London (SYNTHESYS project GB-TAF-4565), the Naturhistoriska riksmuseet, Stockholm (SYNTHESYS project SE-TAF-4765), and the Naturhistorisches Museum, Vienna (SYNTHESYS project AT-TAF-2526). The authors are particularly grateful to Ronald Parsley (Tulane University, New Orleans) and Sergei Rozhnov (Russian Academy of Sciences, Moscow) for their constructive reviews, and to Marcello Ruta (Bristol University, Bristol) for his helpful comments. The authors also express their gratitude to Didier Berthet (Musée des Confluences, Lyon), Petr Budil (Czech Geological Survey, Prague), Pierre Dalous, Guillaume Fleury and Yves Laurent (Muséum d'Histoire naturelle, Toulouse), Tim Ewin (Natural History Museum, London), Khadija El Hariri (Université Cadi Ayyad, Marrakech), Christina Franzén-Bengtson (Naturhistoriska riksmuseet, Stockholm), Andreas Kroh (Naturhistorisches Museum, Vienna), Anne Médard and Sylvie Pichard (Muséum d'Histoire naturelle, Marseille), Christian Neumann (Museum für Naturkunde, Berlin), Abel Prieur and Emmanuel Robert (Université Lyon 1, Villeurbanne), Rudolf Prokop (National Museum, Prague), Roland and Véronique Reboul (Saint-Chinian), Pedro Viegas (Bristol University, Bristol), and Samuel Zamora (Museo Paleontológico de la Universidad, Zaragoza), for their kind assistance and the access to the material.

\section{References}

Allasinaz, A. 1999. Invertebrati fossili. 809 pp. Unione Tipografico - Editrice Torinese, Torino.

Aronson, R.B. \& BlaKe, D.B. 1997. Evolutionary paleoecology of dense ophiuroid populations. Paleontological Society Papers 3, 107-119.
Arroyo, F. \& Lara, R. 2002. Catálogo de las especies de equinodermos s.l. del Ordovícico español. Coloquios de Paleontología 53, 87-108.

Ausich, W.I., Gil Cid, M.D. \& Dominguez Alonso, P. 2002. Ordovician [Dobrotivian (Llandeilian Stage) to Ashgill] crinoids (phylum Echinodermata) from the Montes de Toledo and Sierra Morena, Spain with implications for paleogeography of Peri-Gondwana. Journal of Paleontology 76, 975-992. DOI 10.1666/0022-3360(2002)076<0975:ODLSTA >2.0.CO;2

BARRANDE, J. 1867. Systême silurien du centre de la Bohême. lère partie: Recherches paléontologiques. Volume 3. Classe des Mollusques. Ordre des Ptéropodes. 179 pp. Bellmann, Prague.

BARRAnde, J. 1872. Systême silurien du centre de la Bohême. Supplément au Volume 1. Trilobites, Crustacés divers et Poissons. 647 pp. Bellman, Prague.

BARRANDE, J. 1887. Systême silurien du centre de la Bohême. lère partie: Recherches paléontologiques. Volume 7. Classe des Echinodermes. Ordre des Cystidées. 233 pp. Gerhard, Leipzig \& Řivnáč, Prague.

BASSLER, R.S. 1915. Bibliographic index of American Ordovician and Silurian fossils. Volume 1. United States National Museum 92, 1-718. DOI 10.5479/si.03629236.92

BASSLER, R.S. 1938. Pelmatozoa Palaeozoica (Generum et Genotyporum Index et Bibliographia). Fossilium Catalogus I Animalia 83, 1-194.

BASSLER, R.S. \& Moodey, M.W. 1943. Bibliographic and faunal index of Paleozoic pelmatozoan echinoderms. Geological Society of America, Special Papers 45, 1-733.

DOI 10.1130/SPE45-p1

Bather, F.A. 1899. A phylogenetic classification of the Pelmatozoa. Report of the British Association for the Advancement of Science (Section D), 916-923. DOI 10.1017/S0080456800003999

Bather, F.A. 1900. Part 3. The Echinoderma, 1-344. In LANKESTER, E.R. (ed.) A Treatise on Zoology. Adam \& Charles Black, London.

BAtHER, F.A. 1913. Caradocian Cystidea from Girvan. Transactions of the Royal Society of Edinburgh 49, 359-529.

BAtHer, F.A. 1926. Cothurnocystis: a study in adaptation. Paläontologische Zeitschrift 7, 1-15.

DOI 10.1007/BF03161542

BATHER, F.A. 1928. Dendrocystis in North America. Bulletin of the Geological Survey of Canada 49, 5-8.

Benton, M.J. 1993. The Fossil Record. 845 pp. Chapman \& Hall, London.

Billings, E. 1859. On the Crinoideae of the Lower Silurian Rocks of Canada, 7-66. In Geological Survey of Canada (ed.) Figures and Descriptions of Canadian Organic Remains. Decade 4. John Lovell, Montreal.

BLAKE, D.B. 2013. Early asterozoan (Echinodermata) diversification: a paleontologic quandary. Journal of Paleontology 87, 353-372. DOI 10.1666/12-042.1

Blake, D.B. \& Guensburg, T.E. 1994. Predation by the Ordovician asteroid Promopalaeaster on a pelecypod. Lethaia 27, 235-239. DOI 10.1111/j.1502-3931.1994.tb01415.x

Brett, C.E., Moffat, H.A. \& Taylor, W.L. 1997. Echinoderm taphonomy, taphofacies, and Lagerstätten. Paleontological Society Papers 3, 147-190.

Brower, J.C. 1999. A new pleurocystitid rhombiferan echinoderm from the Middle Ordovician Galena Group of northern 
Iowa and southern Minnesota. Journal of Paleontology 73, $129-153$.

Bruguière, J.G. 1791. Tableau Encyclopédique et Méthodique des Trois Règnes de la Nature, contenant l'Helminthologie, ou les vers Infusoires, les vers Intestins, les vers Mollusques, etc., Volume 7. 180 pp. Panckoucke, Paris.

BruthansovÁ, J. \& KRAFT, P. 2003. Pellets independent of or associated with Bohemian Ordovician body fossils. Acta Palaeontologica Polonica 48, 437-445.

CAster, K.E. 1967. Homoiostela, 581-627. In Moore, R.C. (ed.) Treatise on Invertebrate Paleontology. Part S, Echinodermata 1(2). Geological Society of America \& University of Texas Press, Boulder \& Lawrence.

Caster, K.E. 1983. A new Silurian carpoid echinoderm from Tasmania and a revision of the Allanicytidiidae. Alcheringa 7 , 321-335. DOI 10.1080/03115518308619615

Chauvel, J. 1941. Recherches sur les cystoïdes et les carpoïdes armoricains. Mémoires de la Société géologique et minéralogique de Bretagne 5, 1-286.

CHLupÁČ, I. 1993. Geology of the Barrandian. A field trip guide. 163 pp. Kramer, Frankfurt-am-Main.

Chlupáč, I., Havlí̌̌eK, V., KŘižž, J., Kukal, Z. \& ŠTorch, P. 1998. Palaeozoic of the Barrandian (Cambrian to Devonian). 183 pp. Czech Geological Survey, Prague.

CuÉnot, L. 1953. Classe des Hétérostélés, 599-606. In Piveteau, J. (ed.) Traité de Paléontologie. Masson, Paris.

DALEY, P.E.J. 1992. The anatomy of the solute Girvanicystis batheri (?Chordata) from the Upper Ordovician of Scotland and a new species of Girvanicystis from the Upper Ordovician of South Wales. Zoological Journal of the Linnean Society 105, 353-375. DOI 10.1111/j.1096-3642.1992.tb01233.x

DALEY, P.E.J. 1995. Anatomy, locomotion and ontogeny of the solute Castericystis vali from the Middle Cambrian of Utah. Geobios 28, 585-615.

DOI 10.1016/S0016-6995(95)80214-2

DALEY, P.E.J. 1996. The first solute which is attached as an adult: a Mid-Cambrian fossil from Utah with echinoderm and chordate affinities. Zoological Journal of the Linnean Society 117, 405-440. DOI 10.1111/j.1096-3642.1996.tb01659.x

David, B., Lefebvre, B., Mooi, R. \& Parsley, R.L. 2000. Are homalozoans echinoderms? An answer from the extraxial-axial theory. Paleobiology 26, 529-555. DOI 10.1666/0094-8373(2000)026<0529:AHEAAF>2.0.CO;2

DenM, R. 1934. Untersuchungen an Cystoideen des Rheinischen Unterdevons. Sitzungsberichte der Bayerischen Akademie der Wissenschaften, Mathematisch-naturwissenschaftliche Abteilung, Sonderdruck aus dem Jahrgang 1934, 19-34.

DeLINE, B. 2008. The first evidence of predatory or parasitic drilling in stylophoran echinoderms. Acta Palaeontologica Polonica 53, 739-743. DOI 10.4202/app.2008.0416

Dominguez, P., JefFeries, R.P.S. \& GIL CID, M.D. 2002. An annotated check-list of genera and species of carpoids. Coloquios de Paleontología 53, 33-68.

Drost, K., Gerdes, A., Jefferies, T., Linnemann, U., Storey, C. 2011. Provenance of Neoproterozoic and early Paleozoic siliciclastic rocks of the Teplá-Barrandian unit (Bohemian Massif): Evidence from U-Pb detrital zircon ages. Gondwana Research 19, 213-231. DOI 10.1016/j.gr.2010.05.003

DzIK, J. 1999. Evolutionary origin of asymmetry in early metazoan animals, 153-190. In PAl Yi, G., ZucChi, C. \& Caglioti, L. (eds) Advances in Biochirality. Elsevier Science, Amsterdam.
Easton, W.H. 1960. Invertebrate Paleontology. 701 pp. Harper $\&$ Brothers, New York.

Fatka, O., Lerosey-Aubril, R., Budil, P. \& Rak, S. 2013. Fossilised guts in trilobites from the Upper Ordovician Letná Formation (Prague Basin, Czech Republic). Bulletin of Geosciences 88, 95-104. DOI 10.3140/bull.geosci.1329

FAtKa, O. \& Mergl, M. 2009. The "microcontinent" Perunica: status and story 15 years after conception, 65-101. In BASSETT, M.G. (ed.) Early Palaeozoic Peri-Gondwana Terranes: New insights from tectonics and biogeography. Geological Society of London, Special Publications 325.

FRIEDRICH, W.P. 1993. Systematik und Funktionsmorphologie mittelkambrischer Cincta (Carpoidea, Echinodermata). Beringeria 7, 1-190.

Fusita, T. 1992. Dense beds of ophiuroids from the Paleozoic to the Recent: the significance of bathyal populations. Otsuchi Marine Research Centre Reports 18, 25-41.

Gil Cid, M.D., Dominguez Alonso, P., Silvan Pobes, E. \& Escribano Rodenas, M. 1996. Bohemiaecystis jefferiesi $\mathrm{n}$. sp.; primer Cornuta para el Ordovícico español. Estudios Geologicos 52, 313-326.

Gill, E.D. \& CASTER, K.E. 1960. Carpoid echinoderms from the Silurian and Devonian of Australia. Bulletins of American Paleontology 41(185), 1-71.

Guensburg, T.E. \& SprinkLe, J. 2003. The oldest known crinoids (Early Ordovician, Utah) and a new crinoid plate homology system. Bulletins of American Paleontology 364, 1-43.

Gupta, V.J. \& Termier, G. 1978. Lower Palaeozoic Echinodermata from Chandragiri Pass, near Kathmandu, Nepal. Recent Researches in Geology 7, 472-480.

Gutiérrez-Marco, J.C., Rábano, I., Sarmiento, G.N., Aceñolaza, G.F., San Jose M.A., Pieren, A.P., Herranz, P., Couto, H.M. \& PiçARRA, J.M. 1999. Faunal dynamics between Iberia and Bohemia during the Oretanian and Dobrotivian (late Middle - earliest Upper Ordovician), and biogeographic relations with Avalonia and Baltica. Acta Universitatis Carolinae, Geologica 43, 487-490.

HAECKEL, E. 1896. Die Amphorideen und Cystideen. Beiträge zur Morphologie und Phylogenie der Echinodermen. 180 pp. Engelmann, Jena. DOI 10.5962/bhl.title.11404

HavlíčEK, V. 1982. Ordovician in Bohemia: development of the Prague Basin and its benthic communities. Sborník geologických věd, Geologie 37, 103-136.

HAVLíčEK, V. 1989. Climatic changes and development of benthic communities through the Mediterranean Ordovician. Sbornik geologických věd, Geologie 44, 79-116.

Havlíček, V. \& FatKa, O. 1992. Ordovician of the Prague Basin (Barrandian area, Czechoslovakia), 461-472. In WeBBy, B.D. \& LAURIE, J.R. (eds) Global Perspectives on Ordovician Geology. Balkema, Rotterdam.

HAVLÍČEK, V. \& VANĚK, J. 1966. The biostratigraphy of the Ordovician of Bohemia. Sborník geologických věd, Paleontologie 8, 7-69.

Hecker, R.T. 1940. Carpoidea, Eocrinoidea i Ophiocistia nizhnego silura Leningradoskoi oblasti i Estonii. Trudy Paleontologicheskogo instituta Akademii nauk SSSR 9, 5-82.

Hoтchкiss, F.H.C. 2012. Growth zones and extraxial-axial homologies in Asteroidea (Echinodermata). Proceedings of the Biological Society of Washington 125, 106-121.

DOI 10.2988/11-37.1

Hunter, A.W., Lefebvre, B., NARdin, E., RéGnault, S., Van Roy, 
P. \& ZAMORA, S. 2010. New echinoderm Lagerstätten from the Upper Ordovician of the eastern Anti-Atlas, Morocco, 23-30. In Harris, L.G., BöttGer, S.A., WALKer, C.W. \& Lesser, M.P. (eds) Echinoderms: Durham. Balkema, Leiden.

JAEKEL, O. 1901. Ueber Carpoideen, eine neue Klasse von Pelmatozoen. Zeitschrift der Deutschen geologischen Gesellschaft 52, 661-677.

JAEKEL, O. 1903. Asteriden und Ophiuriden aus dem Silur Böhmens. Zeitschrift der Deutschen geologischen Gesellschaft 55, 106-113.

JAEKel, O. 1918. Phylogenie und System der Pelmatozoen. Paläontologische Zeitschrift 3, 1-124. DOI 10.1007/BF03190413

JEFFERIES, R.P.S. 1986. The Ancestry of the Vertebrates. 376 pp. British Museum (Natural History), London.

JEFFERIES, R.P.S. 1990. The solute Dendrocystoides scoticus from the Upper Ordovician of Scotland and the ancestry of chordates and echinoderms. Palaeontology 33, 631-679.

Jell, P.A. 1983. Early Devonian echinoderms from Victoria (Rhombifera, Blastoidea and Ophiocistioidea). Memoirs of the Association of Australasian Palaeontologists 1, 209-235.

Jell, P.A. \& Holloway, D. 1982. Anal structure in Rutroclypeus Withers, 1933. Alcheringa 6, 42. DOI 10.1080/03115518208565418

KÁCHA, P. \& Š ARIČ, R. 2009. Host preferences in Late Ordovician (Sandbian) epibenthic bryozoans: example from the Zahořany Formation of Prague Basin. Bulletin of Geosciences 84, 169-178. DOI 10.3140/bull.geosci.1048

KLeIN, J.T. 1734. Naturalis dispositio Echinodermatum. Accessit lucubratiuncula de Aculeis Echinorum Marinorum, cum spicilegio de Belemnitis. 79 pp. Schreiber, Gedani. DOI 10.5962/bhl.title.65731

KolatA, D.R. 1973. Scalenocystites strimplei, a new Middle Ordovician belemnocystitid solute from Minnesota. Journal of Paleontology 47, 969-974.

Kolata, D.R., Strimple, H.L. \& Levorson, C.O. 1977. Revision of the Ordovician carpoid family Iowacystidae. Palaeontology 20, 529-557.

Kröger, B., SERVAIs, T. \& Zhang, Y. 2009. The origin and rise of pelagic cephalopods in the Ordovician. Plos One 4, e7262. DOI 10.1371/journal.pone.0007262

Lefebvre, B. 2000. Homologies in Stylophora: a test of the "calcichordate theory". Geobios 33, 359-364.

DOI 10.1016/S0016-6995(00)80163-1

LeFEBvRE, B. 2001. Some critical comments on "ankyroids". Geobios 34, 597-627. DOI 10.1016/S0016-6995(01)80024-3

Lefebvre, B. 2003. Functional morphology of stylophoran echinoderms. Palaeontology 46, 511-555. DOI 10.1111/1475-4983.00309

Lefebvre, B. 2007. Early Palaeozoic palaeobiogeography and palaeoecology of stylophoran echinoderms. Palaeogeography, Palaeoclimatology, Palaeoecology 245, 156-199. DOI 10.1016/j.palaeo.2006.02.021

Lefebvre, B., Derstler, K. \& Sumrall, C.D. 2012. A reinterpretation of the solutan Plasiacystis mobilis (Echinodermata) from the Middle Ordovician of Bohemia, 287-306. In KROH, A. \& ReIch, M. (eds) Echinoderm Research 2010: Proceedings of the Seventh European Conference on Echinoderms, Göttingen, Germany, 2-9 October 2010. Zoosymposia 7.

Lefebvre, B. \& Fatka, O. 2003. Palaeogeographical and palaeoecological aspects of the Cambro-Ordovician radiation of echinoderms in Gondwanan Africa and peri-Gondwanan Europe. Palaeogeography, Palaeoclimatology, Palaeoecology 195, 73-97. DOI 10.1016/S0031-0182(03)00303-1

Lefebvre, B., Nardin, E., Hunter, A.W. \& Régnault, S. 2007. Les échinodermes de l'Ordovicien supérieur de l'Anti-Atlas (Maroc): biostratigraphie et paléodiversité. Africa Geoscience Review 14, 123-148.

Lefebvre, B., Noailles, F., Franzin, B., Régnault, S., Nardin, E., Hunter, A.W., Zamora, S., Van Roy, P., El Hariri, K. \& LAZREQ, N. 2010. Les gisements à échinodermes de l'Ordovicien supérieur de l'Anti-Atlas oriental (Maroc): un patrimoine scientifique exceptionnel à préserver. Bulletin de l'Institut Scientifique, Rabat 32, 1-17.

Lefebvre, B., Rozhnov, S.V. \& FatKa, O. 2005. Lower Palaeozoic "carpoid" echinoderms of Baltica: palaeoecological and palaeobiogeographic implications, 68-69. In Koren, T., Evdokimova, I. \& Tolmacheva, T. (eds) Abstracts, The Sixth Baltic Stratigraphical Conference, August 23-25, St. Petersburg.

Lefebvre, B., Sumrall, C.D., Shroat-Lewis, R.A., Reich, M., Webster, G.D., Hunter, A.W., Nardin, E., Rozhnov, S.V., Guensburg, T.E., Touzeau, A., Noailles, F. \& Sprinkle, J. in press. Palaeobiogeography of Ordovician echinoderms. In Harper, D.A.T. \& Servais, T. (eds) Early Palaeozoic Palaeobiogeography and Palaeogeography. Geological Society of London, Memoir 38.

Martí Mus, M. 2009. Primeros Equinodermos, 450-457. In Martínez-Chacón, M.L. \& Rivas, P. (eds) Paleontologia de Invertebrados. Universidad de Oviedo, Oviedo.

Moret, L. 1958. Manuel de Paléontologie Animale. 771 pp. Masson, Paris.

MikULÁš, R. 1999. Joint occurrences of body- and trace-fossil communities (Ordovician, Barrandian area, Czech Republic). Journal of the Czech Geological Society 44, 69-78.

MikUláš, R., PEtr, V. \& Prokop, R. 1995. The first occurrence of a "brittlestar bed" (Echinodermata, Ophiuroidea) in Bohemia (Ordovician, Czech Republic). Věstník Českého geologického ústavu 70, 17-24.

Miller, S.A. \& GuRley, W.F.E. 1894. New genera and species of Echinodermata. Illinois State Museum of Natural History 5, $5-53$.

MooI, R., David, B. \& Marchand, D. 1994. Echinoderm skeletal homologies: classical morphology meets modern phylogenetics, 87-95. In David, B., Guille, A., Féral, J.P. \& RouX, M. (eds) Echinoderms through Time. Balkema, Rotterdam.

Nardin, E., Lefebvre, B., David, B. \& Mooi, R. 2009. La radiation des échinodermes au Paléozoïque inférieur, l'exemple des blastozoaires. Comptes Rendus Palevol 8, 179-188. DOI 10.1016/j.crpv.2008.09.004

Neumayr, M. 1889. Die Stämme des Thierreiches. Wirbellose Thiere, volume 1. 603 pp. Tempsky, Vienna \& Prague.

Nichols, D. 1962 . Echinoderms. 200 pp. Hutchinson \& Co., London.

Nichols, D. 1972. The water-vascular system in living and fossil echinoderms. Palaeontology 15, 519-538.

PARSLEY, R.L. 1970. Revision of the North American Pleurocystitidae (Rhombifera - Cystoidea). Bulletins of American Paleontology 58, 135-213.

PARSLEY, R.L. 1972. The Belemnocystitidae: solutan homeomorphs of the Anomalocystitidae. Journal of Paleontology 46, 341-347. 
PARsLey, R.L. 1982. Homalozoans, 322-323. In SPRINKLE, J. (ed.) Echinoderm Faunas from the Bromide Formation (Middle Ordovician) of Oklahoma. University of Kansas Paleontological Contributions, Monograph 1.

PARSLEY, R.L. 1990. Aristocystites, a recumbent diploporid (Echinodermata) from the Middle and Late Ordovician of Bohemia (ČSSR). Journal of Paleontology 64, 278-293.

Parsley, R.L. 1997. The echinoderm classes Stylophora and Homoiostelea: non Calcichordata. Paleontological Society Papers 3, 225-248.

Parsley, R.L. 1998. Community setting and functional morphology of Echinosphaerites infaustus (Fistuliporita: Echinodermata) from the Ordovician of Bohemia. Věstník Českého geologického ústavu 73, 253-265.

PARsley, R.L. 1999. The Cincta (Homostelea) as blastozoans, 369-375. In Candia Carnevali, M.D. \& Bonasoro, F. (eds) Echinoderm Research 1998. Balkema, Rotterdam.

Parsley, R.L. \& CASTer, K.E. 1965. North American Soluta (Carpoidea, Echinodermata). Bulletins of American Paleontology 49(221), 109-174.

Parsley, R.L., Rozhnov, S.V. \& Sumrall, C.D. 2012. Morphologic and systematic revision of the solute Maennilia estonica (Homoiostelea, Echinodermata) from the Upper Ordovician of Estonia. Journal of Paleontology 86, 462-469. DOI 10.1666/11-083.1

Parsley, R.L. \& Sumrall, C.S. 2007. New recumbent echinoderm genera from the Bois d'Arc Formation: Lower Devonian (Lochkovian) of Coal County, Oklahoma. Journal of Paleontology 81, 1486-1493. DOI 10.1666/04-072.1

PAuL, C.R.C. 1967. The functional morphology and mode of life of the cystoid Pleurocystites E. Billings, 1854, 105-123. In MiLot, E. (ed.) Echinoderm Biology. Symposium of the Zoological Society of London 20.

Paul, C.R.C. 1984. British Ordovician cystoids, part 2. Palaeontolographical Society Monographs 136, 65-152.

Peterson, K.J., Arenas-Mena, C. \& Davidson, E.H. 2000. The $\mathrm{A} / \mathrm{P}$ axis in echinoderm ontogeny and evolution: evidence from fossils and molecules. Evolution \& Development 2, 93-101. DOI 10.1046/j.1525-142x.2000.00042.x

Petr, V. 1989a. Revision of morphology and ecology of Bohemura jahni Jaekel, 1903 (Ophiuroidea, Protasteridae) from Bohemian Middle Ordovician. Sborník Národního muzea v Praze 45, 1-20.

Petr, V. 1989b. Two new species of brittle-stars (Ophiuroidea, Protasteridae) from the Upper Ordovician of Bohemia. Sborník Národního muzea v Praze 45, 61-71.

PhiliP, G.M. 1979. Carpoids - echinoderms or chordates? Biological Reviews 54, 439-471.

DOI 10.1111/j.1469-185X.1979.tb00845.x

Prokop, R.J. 1984. Revision of the genus Polycrinus Jaekel, 1918 (Crinoidea, Inadunata) from the Upper Ordovician of Bohemia. Časopis pro mineralogii a geologii 29, 181-184.

PRokop, R.J. \& PetR, V. 1990. Letenocrinus longibrachialis gen. et sp. n. (Echinodermata, Paracrinoidea?) from the Bohemian Middle Ordovician. Časopis Národního muzea, $\check{R} a d a$ přirodovědná 155, 105-108.

Prokop, R.J. \& Petr, V. 1999. Echinoderms in the Bohemian Ordovician. Journal of the Czech Geological Society 44, 63-68.

Prokop, R.J. \& Petr, V. 2003. Plasiacystis mobilis gen. et sp. n., a strange "carpoid" (Echinodermata, ?Homoiostelea: Soluta) in the Bohemian Ordovician (Czech Republic). Sborník Národ-

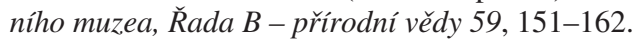

Rahman, I.A. \& Lintz, H. 2012. Dehmicystis globulus, an enigmatic solute (Echinodermata) from the Lower Devonian Hunsrück Slate, Germany. Paläontologische Zeitschrift 86, $59-70$.

RAK, S. 2009. The occurrence of non-trilobite arthropods from the quartzites of Letná Formation. Český kras 35, 14-25.

RegnéLl, G. 1945. Non-crinoid Pelmatozoa from the Paleozoic of Sweden. Meddelanden från Lunds Geologisk-Mineralogiska Institution 108, 1-255.

RozHnov, S.V. 2002. Morphogenesis and evolution of crinoids and other pelmatozoan echinoderms in the Early Palaeozoic. Paleontological Journal 36 (Suppl. 6), 525-674.

Rozhnov, S.V. 2012. The anteroposterior axis in echinoderms and displacement of the mouth in their phylogeny and ontogeny. Biology Bulletin 39, 162-171.

DOI 10.1134/S1062359012020094

Rozhnov, S.V. \& JEFFERIES, R.P.S. 1996. A new stem-chordate solute from the Middle Ordovician of Estonia. Geobios 29, 91-109. DOI 10.1016/S0016-6995(96)80074-X

Servais, T. \& Sintubin, M. 2009. Avalonia, Armorica, Perunica: terranes, microcontinents, microplates or palaeobiogeographical provinces?, 103-115. In BAssetT, M.G. (ed.) Early Palaeozoic Peri-Gondwana Terranes: New insights from tectonics and biogeography. Geological Society of London, Special Publications 325.

Sevastopulo, G.D. 2008. Paleobiology of Carboniferous microcrinoids, 55-69. In Ausich, W.I \& Webster, G.D. (eds) Echinoderm Paleobiology. Indiana University Press, Bloomington.

Smith, A.B. 2005. The pre-radial history of echinoderms. Geological Journal 40, 255-280. DOI 10.1002/gj.1018

SMITH, A.B. 2008. Deuterostomes in a twist: the origins of a radical new body plan. Evolution \& Development 10, 493-503. DOI 10.1111/j.1525-142X.2008.00260.x

Sмith, A.B. \& Zamora, S. 2009. Rooting phylogenies of problematic fossil taxa; a case study using cinctans (stem-group echinoderms). Palaeontology 52, 803-821. DOI 10.1111/j.1475-4983.2009.00880.x

Spencer, W.K. \& Wright, C.W. 1966. Asterozoans, 4-107. In Moore, R.C. (ed.) Treatise on Invertebrate Paleontology. Part U, Echinodermata 3(1). Geological Society of America \& University of Texas Press, Boulder \& Lawrence.

Sprinkle, J. 1973. Morphology and Evolution of Blastozoan Echinoderms. 283 pp. Museum of Comparative Zoology Harvard University, Cambridge (Massassuchetts).

SpRinkLe, J. 1974. New rhombiferan cystoids from the Middle Ordovician of Nevada. Journal of Paleontology 48, 1174-1201.

SPRINKLE, J. 1976. Biostratigraphy and paleoecology of Cambrian echinoderms from the Rocky Mountains. Brigham Young University Geology Studies 23, 61-73.

SPRINKLE, J. 1992. Radiation of Echinodermata, 375-398. In LiPPS, J.H. \& Signor, P.W. (eds) Origin and Early Evolution of the Metazoa. Plenum Press, New York.

SprinkLe, J. \& Guensburg, T.E. 2001. Growing a stalked echinoderm within the Extraxial-Axial Theory, 59-65. In BARKER, M.F. (ed.) Echinoderms 2000. Swets \& Zeitlinger, Lisse.

Sprinkle, J. \& Guensburg, T.E. 2004. Crinozoan, blastozoan, echinozoan, asterozoan, and homalozoan echinoderms, 266-280. In Webby, B.D., Paris, F., Droser, M.L. \& PercivaL, I.G. (eds) The Great Ordovician Biodiversification Event. Columbia University Press, New York. 
Sprinkle, J. \& Kier, P.M. 1987. Phylum Echinodermata, 550-611. In Boardman, R.S., Cheetham, A.H. \& Rowell, A.J. (eds) Fossil Invertebrates. Blackwell, London.

Štorch, P., FAtKa, O. \& KRAFT, P. 1993. Lower Palaeozoic of the Barrandian area (Czech Republic) - a review. Coloquios de Paleontologia 45, 163-191.

StRimple, H.L. 1953. A new carpoid from Oklahoma. Journal of the Washington Academy of Sciences 43, 105-106.

Sumrall, C.D. 1997. The role of fossils in the phylogenetic reconstruction of Echinodermata. Paleontological Society Papers 3, 267-288.

Sumrall, C.D. 2000. The biological implications of an edrioasteroid attached to a pleurocystitid rhombiferan. Journal of Paleontology 74, 67-71. DOI 10.1666/0022-3360(2000)074<0067:TBIOAE >2.0.CO;2

Sumrall, C.D., Sprinkle, J. \& Guensburg, T.E. 1997. Systematics and paleoecology of Late Cambrian echinoderms from the western United States. Journal of Paleontology 71, 1091-1109.

Sumrall, C.D., Sprinkle, J., Guensburg, T.E. \& Dattilo, B.F. 2012. Early Ordovician mitrates and a possible solute (Echinodermata) from the western United States. Journal of Paleontology 86, 595-604. DOI 10.1666/10-165R.1

TALENT, J.A. 1990. Himalayan geology again: curiouser and spuriouser! The Australian Geologist 74, 42-46.

Termier, H. \& Termier, G. 1948. Les échinodermes du Paléozoïque inférieur. La Revue Scientifique 3298, 613-626.

THAYER, C.W. 1975. Morphologic adaptations of benthic invertebrates to soft substrata. Journal of Marine Research 3, $177-189$.

Thomas, A.O. \& LAdD, H.S. 1926. Additional cystoids and crinoids from the Maquoketa Shale of Iowa. University of Iowa Studies in Natural History 11, 5-18.

Thoral, M. 1935. Contribution à l'étude paléontologique de l'Ordovicien inférieur de la Montagne Noire et révision sommaire de la faune cambrienne de la Montagne Noire. 362 pp. Imprimerie de la Charité, Montpellier.

UbAGHS, G. 1960. Le genre Lingulocystis Thoral (Echinodermata, Eocrinoidea), avec des remarques critiques sur la position systématique du genre Rhipidocystis Jaekel. Annales de Paléontologie 46, 81-116.

Ubaghs, G. 1963. Cothurnocystis Bather, Phyllocystis Thoral and an undetermined member of the order Soluta (Echinodermata, Carpoidea) in the uppermost Cambrian of Nevada. Journal of Paleontology 37, 1133-1142.

Ubaghs, G. 1966. Ophiocistioids, 174-188. In Moore, R.C. (ed.) Treatise on Invertebrate Paleontology. Part U, Echinodermata 3(1). Geological Society of America \& University of Texas Press, Boulder \& Lawrence.

Ubaghs, G. 1967a. Eocrinoidea, 455-495. In Moore, R.C. (ed.) Treatise on Invertebrate Paleontology. Part S, Echinodermata 1(2). Geological Society of America \& University of Texas Press, Boulder \& Lawrence.

Ubaghs, G. 1967b. Stylophora, 495-565. In Moore, R.C. (ed.) Treatise on Invertebrate Paleontology. Part S, Echinodermata 1(2). Geological Society of America \& University of Texas Press, Boulder \& Lawrence.

Ubaghs, G. 1967c. Homostela, 565-581. In Moore, R.C. (ed.) Treatise on Invertebrate Paleontology. Part S, Echinoder- mata 1(2). Geological Society of America \& University of Texas Press, Boulder \& Lawrence.

Ubaghs, G. 1970. Les échinodermes “carpoïdes” de l'Ordovicien inférieur de la Montagne Noire (France). 110 pp. Editions du CNRS (Cahiers de Paléontologie), Paris.

Ubaghs, G. 1979. Trois Mitrata (Echinodermata: Stylophora) nouveaux de l'Ordovicien de Tchécoslovaquie. Paläontologische Zeitschrift 53, 98-119. DOI 10.1007/BF02987791

Ubaghs, G. 1981. Réflexions sur la nature et la fonction de l'appendice articulé des "carpoïdes" Stylophora (Echinodermata). Annales de Paléontologie 67, 33-48.

Ubaghs, G. \& Robison, R.A. 1985. A new homoiostelean and a new eocrinoid from the Middle Cambrian of Utah. University of Kansas Paleontological Contributions 115, 1-24.

UbAGHS, G. \& RoBison, R.A. 1988. Homalozoan echinoderms of the Wheeler Formation (Middle Cambrian) of western Utah. University of Kansas Paleontological Contributions 120, $1-17$.

WaAgen, W. \& JAhn, J.J. 1899. Classe des Echinodermes. 2, Famille des Crinoïdes, 1-215. In BARRAnde, J. (ed.) Systême silurien du centre de la Bohême 7. Gerhard, Leipzig \& Řivnáč, Prague.

Wachsmuth, C. \& Springer, F. 1881. Revision of the Palaeocrinoidea. Proceedings of the Academy of Natural Sciences of Philadelphia, 177-414.

Webster, G.D. 1991. An evaluation of the V.J. Gupta echinoderm papers, 1971-1989. Journal of Paleontology 65, 1006-1008.

Wetherby, A.G. 1881. Descriptions of new fossils from the Lower Silurian and sub-Carboniferous rocks of Kentucky. Journal of the Cincinnati Society of Natural History 4, 177-179.

Withers, R.B. 1933. A new genus of fossil king crabs. Proceedings of the Royal Society of Victoria 46, 18-22.

ZAMORA, S., DARROCH, S. \& RAHMAN, I.A. 2013. Taphonomy and ontogeny of early pelmatozoan echinoderms: a case study of a mass-mortality assemblage of Gogia from the Cambrian of North America. Palaeogeography, Palaeoclimatology, Palaeoecology 377, 62-72. DOI 10.1016/j.palaeo.2013.03.009

Zamora, S., Lefebvre, B., Alvaro, J.J., Clausen, S., Elicki, O., Fatka, O., Jell, P., Kouchinsky, A., Lin, J.P., Nardin, E., Parsley, R.L., Rozhnov, S.V., Sprinkle, J., Sumrall, C.D., Vizcaïno, D. \& SMith, A.B. in press. Cambrian echinoderm diversity and palaeobiogeography. In HARPER, D.A.T \& Servais, T. (eds) Early Palaeozoic Palaeobiogeography and Palaeogeography. Geological Society of London, Memoir 38.

ZAmora, S., Zhu, X. \& Lefebvre, B. 2012. Palaeogeographic and evolutionary implications of new Furongian (Cambrian) echinoderms from China. Conference booklet, $14^{\text {th }}$ International Echinoderm Conference, 20-24 August 2012, Brussels, 137.

ZitTel, K.A. von 1903. Grundzüge der Paläontologie (Paläozoologie). I. Abteilung: Invertebrata. $558 \mathrm{pp}$. Oldenbourg, Munich \& Berlin. DOI 10.5962/bhl.title.61799

ZuYkov, M.A., Terentiev, S.S. \& HARPER, D.A.T. 2008. New endemic brachiopod and echinoderm genera from the Upper Ordovician of the St. Petersburg region, northwestern Russia. GFF 130, 87-93. DOI 10.1080/11035890801302087 